\title{
The Equity Share in New Issues and Aggregate Stock Returns
}

\author{
MALCOLM BAKER and JEFFREY WURGLER*
}

\begin{abstract}
The share of equity issues in total new equity and debt issues is a strong predictor of U.S. stock market returns between 1928 and 1997. In particular, firms issue relatively more equity than debt just before periods of low market returns. The equity share in new issues has stable predictive power in both halves of the sample period and after controlling for other known predictors. We do not find support for efficient market explanations of the results. Instead, the fact that the equity share sometimes predicts significantly negative market returns suggests inefficiency and that firms time the market component of their returns when issuing securities.
\end{abstract}

IN THEIR CLASSIC PROOF of the irrelevance of financing policy, Modigliani and Miller (1958) implicitly assume market efficiency. If the stock market is inefficient, however, financing policy becomes relevant in obvious ways. When equity prices are too high, existing shareholders benefit by issuing overvalued equity. When equity prices are too low, issuing debt is preferable.

Consistent with this timing hypothesis, firms issuing equity have poor subsequent performance. Stigler (1964), Ritter (1991), Loughran and Ritter (1995), and Speiss and Affleck-Graves (1995) find low average returns after both initial and seasoned offerings. ${ }^{1}$ These studies focus exclusively on issuer returns relative to some benchmark-the first term in the decomposition $R_{i}=\left(R_{i}-R_{b}\right)+R_{b}$. The benchmark is typically the market portfolio or

\footnotetext{
* Baker is from Harvard University. Wurgler is from the Yale School of Management. We would like to thank John Campbell, Paul Gompers, Jean Helwege, Owen Lamont, Tim Loughran, Scott Mayfield, Tom McCraw, Jay Ritter, Bob Shiller, Jeremy Stein, René Stulz, seminar participants at Harvard University, the National Bureau of Economic Research, and the Yale School of Management, and especially Andrei Shleifer for helpful comments. We thank Leslie Jeng, S.P. Kothari, Charles Lee, and CDA Weisenberger for providing data. The issues data series transcribed from the Federal Reserve Bulletin are available on Wurgler's home page, currently http://som.yale.edu/ jaw52. This study has been supported by the Division of Research of the Harvard Graduate School of Business Administration.

${ }^{1}$ See also Friend and Herman (1964), Friend and Longstreet (1967), Weiss (1989), Peavy (1990), Jain and Kini (1994), Lerner (1994), Ikenberry, Lakonishok, and Vermaelen (1995), Mikkelson, Partch, and Shah (1997), Rajan and Servaes (1996), Loughran and Ritter (1997), Loughran and Vijh (1997), Pagano, Panetta, and Zingales (1998), Cornett, Mehran, and Tehranian (1998), Teoh, Welch, and Wong (1998a, 1998b), and Ahn and Shivdasani (1999) for other empirical results that suggest managers time the equity market. However, some authors challenge the idea that firms successfully time the idiosyncratic portion of their returns (Brav and Gompers (1997), Brav, Geczy and Gompers (2000), Eckbo, Masulis, and Norli (2000)).
} 
some other portfolio that moves with the market. But equity issues tend to cluster around market peaks, as shown by Loughran, Ritter, and Rydqvist (1994) and other studies of "hot issue markets." This suggests that issuers try to time both their idiosyncratic return and the market return. In this paper, we consider the second possibility.

The empirical financing variable we focus on is the share of equity issues in total equity and debt issues, calculated from data reported in the Federal Reserve Bulletin. In the typical year between 1927 and 1996, equity issues represent about 21 percent of the value of all new issues. This share increases right after a year of high equity market returns. More interestingly, firms issue relatively more equity just before years of low market returns. For example, when the equity share in new issues is in the bottom historical quartile (below 0.14), the average CRSP value-weighted market return in the next year is 14 percent. When the equity share is in the top historical quartile (above 0.27), the average return in the next year is -6 percent. The difference in equal-weighted market returns is even larger, 27 percent versus -8 percent.

In terms of sheer univariate predictive power, the equity share in new issues is a stronger predictor of one-year-ahead returns than the dividendto-price ratio or the book-to-market ratio. It is also statistically significant and of stable magnitude in both the first and second half of the sample. Scaled-price variables, by contrast, do not achieve this level of robustness. Finally, the equity share adds incremental predictive power to the scaledprice variables and other known predictors.

The main question is whether these results have an explanation consistent with market efficiency. We consider three explanations. The first and simplest one is that issuing more equity than debt reduces required equity returns through a textbook Modigliani and Miller leverage effect. However, a simple calculation shows that the size of the equity share coefficient is over 20 times too large to be due to this effect alone. Because new issues represent only a small fraction of outstanding capital, they do not influence aggregate leverage enough to change expected equity returns.

A second potential explanation is that the equity share is related to future returns through investment. We use a simple representative firm model based on Stein (1996) to understand how investment and financing decisions differ in efficient versus inefficient capital markets. In the efficient market case, if the rational discount rate falls, firms increase investment. If firms follow a pecking-order financing policy, they will also tend to increase the equity share in new issues at the same time they increase investment, giving rise to our main result. However, in the data, aggregate investment is essentially unrelated to subsequent aggregate returns. This conflicts with the efficient market case of the model, which predicts a negative relationship. By contrast, when mispricing is the primary cause of predictable variation in returns, the model illustrates how the equity share may respond to future returns even when investment does not. The empirical analysis in this section also indicates that the equity share in new equity and debt issues has somewhat more power to predict market returns than the absolute level of equity issues. 
A third potential explanation is that an unobserved factor such as market risk may simultaneously change both optimal capital structure and required returns in a way that induces a relationship between the equity share and future returns. However, standard theories of optimal capital structure point toward a positive, not negative, relationship between the equity share and future returns. That is, when expected returns go up with risk, the probability of financial distress for a given capital structure rises. And if tax schedules are convex, the expected benefit of debt tax shields falls. Given that the costs of leverage increase and the benefits fall, higher risk and returns demand more equity, not less. But even if one conjectures the opposite, this channel does not receive empirical support: the predictive power of the equity share does not diminish after controlling for aggregate leverage directly.

In sum, we do not find support for any of these efficient market explanations for the results. We may have overlooked other potential explanations, but one fact gives pause: the results imply a statistical model of market returns that sometimes predicts significantly negative returns. Because expected returns on the market overall are likely to be positive in any rational model, it is hard to square this with market efficiency. This approach to testing market efficiency has been taken by Fama and Schwert (1977) with the short rate, Fama and French (1988a) with the aggregate dividend yield, and Kothari and Shanken (1997) with the aggregate book-to-market. In contrast to the results of those studies, we find that the equity share sometimes predicts significantly negative returns even for the value-weighted market. This evidence, and the fact that we cannot find support for any particular efficient market explanation, leads us to conclude that managerial timing of an inefficient equity market is the most credible explanation of our results.

Finally, we would like to mention an interesting and related paper by Nelson (1999), which, like Loughran et al. (1994) and this paper, also considers the relationship between aggregate financing patterns and aggregate stock returns. ${ }^{2}$ Nelson's paper can be distinguished from this paper in a few ways. First, he uses the percentage change in shares outstanding as the financing variable of interest, whereas we use gross new equity issues scaled by gross new equity and debt issues. We believe that the equity share variable better isolates timing motives for issuance from pure investment motives and variation in investment opportunities. Nelson's net series does have the advantage of controlling for repurchases. (We show in Appendix A that controlling for repurchases makes little practical difference to our results, however.) Second, Nelson focuses on a five-year prediction horizon, whereas we focus on a shorter one-year horizon. Third, we go farther than both Nelson and Loughran et al. in ruling out efficient market explanations of the results.

The paper proceeds as follows. Section I describes the data on aggregate new issues and other data that we use. Section II presents the main empirical results. Section III evaluates efficient market and market timing expla-

\footnotetext{
${ }^{2}$ Lamont (1998) finds that the dividend-payout ratio forecasts high future returns. When dividends are viewed as a source of finance, this predictability is consistent with our findings on the equity share.
} 
nations. Section IV summarizes and discusses some important implications of our results for long-run event studies of managerial actions.

\section{Data}

For a study of equity market timing, the ideal measure of new finance composition is the share of net new corporate finance raised through public equity issues. The key benefit of the equity share is that it isolates potential timing motives from the level of investment itself. Unfortunately, data are not easily available to construct an ideal measure. Net new finance comes from many sources, including internal finance, new bank debt net of retirements, public and private debt issues also net of retirements, and public and privately placed equity issues net of repurchases. Not all of these data series are available for a significant time period. Our approach is to use a relatively unadjusted series of gross new equity and debt issues. We show in Appendix A that various adjustments make little difference to the main results. The data are available at the second author's home page, currently http://som.yale.edu/ jaw52.

\section{A. Aggregate Equity and Debt Issues Data, 1927-1996}

The Federal Reserve Bulletin has reported monthly levels of equity issues (common and preferred) and debt issues (public and private) since 1927. Through 1952, the Bulletin's primary source for issues data is the Commercial and Financial Chronicle. After 1952, the Bulletin reports data gathered by the Securities and Exchange Commission. Our basic data are the annual totals of equity issues (common and preferred) and long-term debt issues (public and private) collected from Bulletin issues between 1927 and 1996. The data series are gross totals of equity and debt issues that do not subtract out repurchases or debt retirements. In Appendix A, we show that adjusting this series by subtracting out repurchases, junk and convertible debt, and utilities issues makes little difference to the main results.

The Federal Reserve Board's flow of funds provides an alternative source of data on net changes in debt and equity for the economy as a whole. In contrast to the series that we use, these net series subtract repurchases and debt retirements. Unfortunately, there are also disadvantages. The first is that the series include exchange issues and retirements associated with merger activity. Merger activity is often an order of magnitude larger than normal operations finance. As a result, mergers tend to drive the flow of funds series. $^{3}$ A second disadvantage of the flow of funds series is that it does not begin until 1946. Nonetheless, in Appendix A, we show that the flow of funds data give similar results. All things considered, we lean toward using the unadjusted gross series in the body of the paper.

\footnotetext{
${ }^{3}$ We thank Jean Helwege and researchers at the Federal Reserve Board for pointing this out.
} 


\section{B. Hot Markets}

The aggregate equity and debt issue series are presented in Figures 1A and 1B. We adjust both to millions of 1995 dollars using the Consumer Price Index. Panel A of Table I reports summary statistics for these series.

Several features of these series are apparent from the plots. First, both series are quite variable. Equity issues are even more variable than debt issues. The standard deviation of the annual growth rate is 96 percent for equity issues and 57 percent for debt issues. Second, hot equity markets, in terms of volume, are apparent. ${ }^{4}$ Figure $1 \mathrm{~A}$ shows at least five hot markets for equity between 1927 and 1996. A peak occurred in 1929, when real new issues surged to $\$ 60$ billion, a level not reached again until 1983. This level is even more astounding when compared to the size of the stock market. In 1929, new equity represented 11.6 percent of the dollar value of outstanding equity reported by CRSP. By contrast, in 1993, another record year, new issues comprised only 2.3 percent of outstanding equity. Equity issues also peaked in 1971, 1983, and 1986. Third, debt issues rose dramatically in the 1980s and again in the early 1990s. Real new debt issues increased by a factor of six between 1982 and 1986. Offerings peaked at $\$ 630$ billion in 1993, about twice the 1986 level. These increases reflect a variety of factors, including lower inflation expectations and a growing market for junk bonds.

The issue series are totals that lump together a few different types of issues. For example, the equity issues include not only IPOs and SEOs of operating companies but also issues by closed-end funds. Unfortunately, it is not possible to disaggregate issues by type for the entire period. But bits of data reported in the Bulletin and other sources give a sense of how uses of new issues capital vary over time. For example, a large number of closed-end funds were started in 1929. The December 1929 Bulletin reports that in the first 10 months of 1929, closed-end company issues represented 42 percent of all domestic corporate security issues. During this period, closed-end funds were priced at large premiums. ${ }^{5}$ The crash sullied the image of these investment companies for decades after, and they do not represent a large portion of more recent equity issues.

Figure 1A does not reveal the fact that net equity issues were actually negative during most of the 1980s and some of the 1990s, as reported in the Federal Reserve Board's flow of funds data. This is a consequence of simultaneous increases in repurchase activity and the use of debt to finance acquisitions (retiring equity in the process). Nevertheless, the share of equity in total new issues was also low during this period, and gives a similar impression of financing patterns as the net equity issues series.

\footnotetext{
${ }^{4}$ Ibbotson and Jaffe (1975) define hot IPO markets as periods during which initial (firstmonth) IPO returns are particularly high.

${ }^{5}$ De Long and Shleifer (1991) discuss closed-end fund issues and discounts around the 1929 crash.
} 

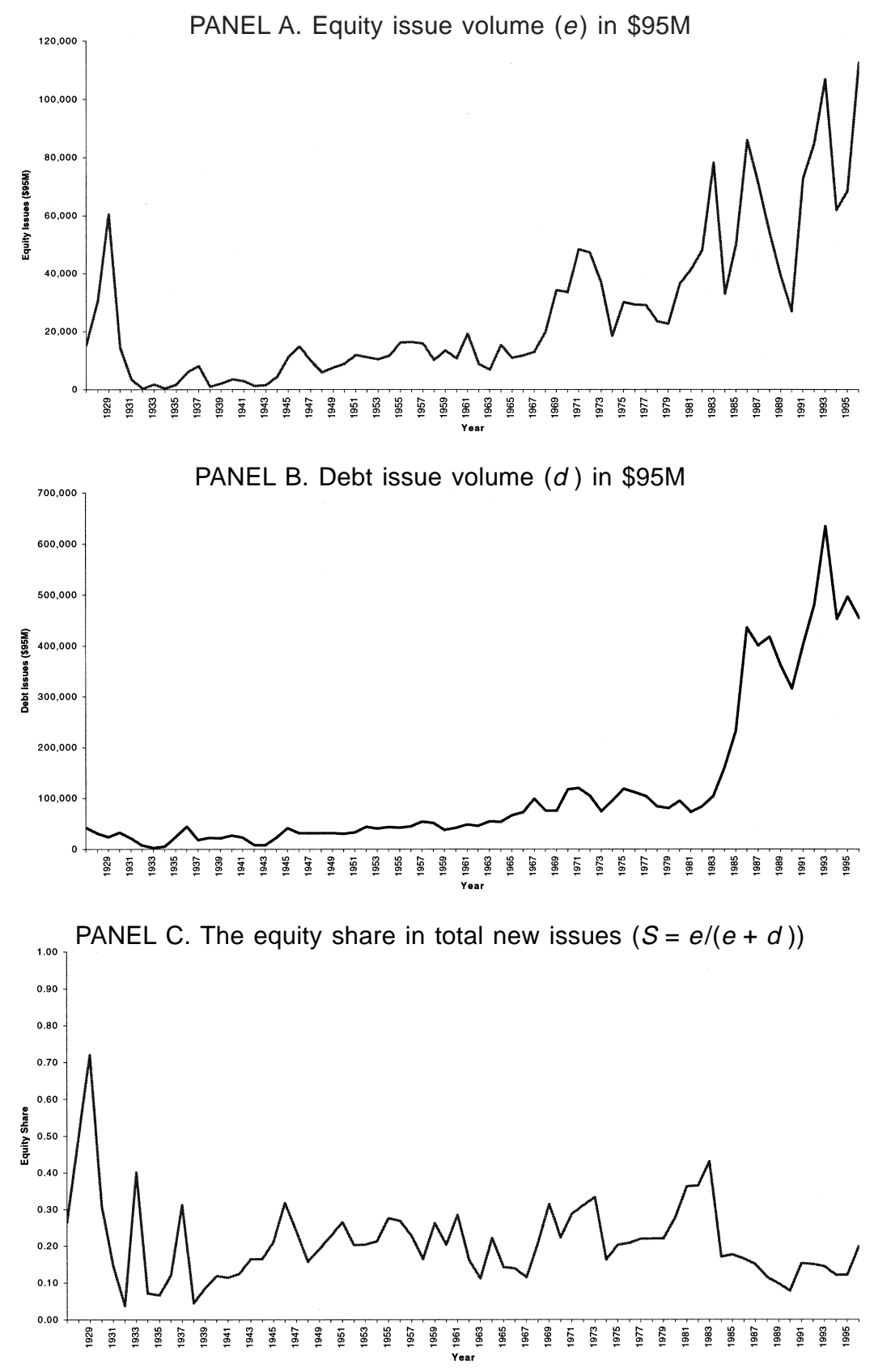

Figure 1. Equity and debt issues, 1927-1996. Equity and debt issue volumes are from the Federal Reserve Bulletin. The equity series (A) includes both common and preferred equity issues. The debt series (B) includes both public and private debt issues. The equity share in total new issues (C) is the fraction of equity issues in total issues. The equity and debt series are converted to 1995 dollars using the Consumer Price Index from Ibbotson Associates (1998). The data are available at the second author's web page, currently http://som.yale.edu/ jaw52. 

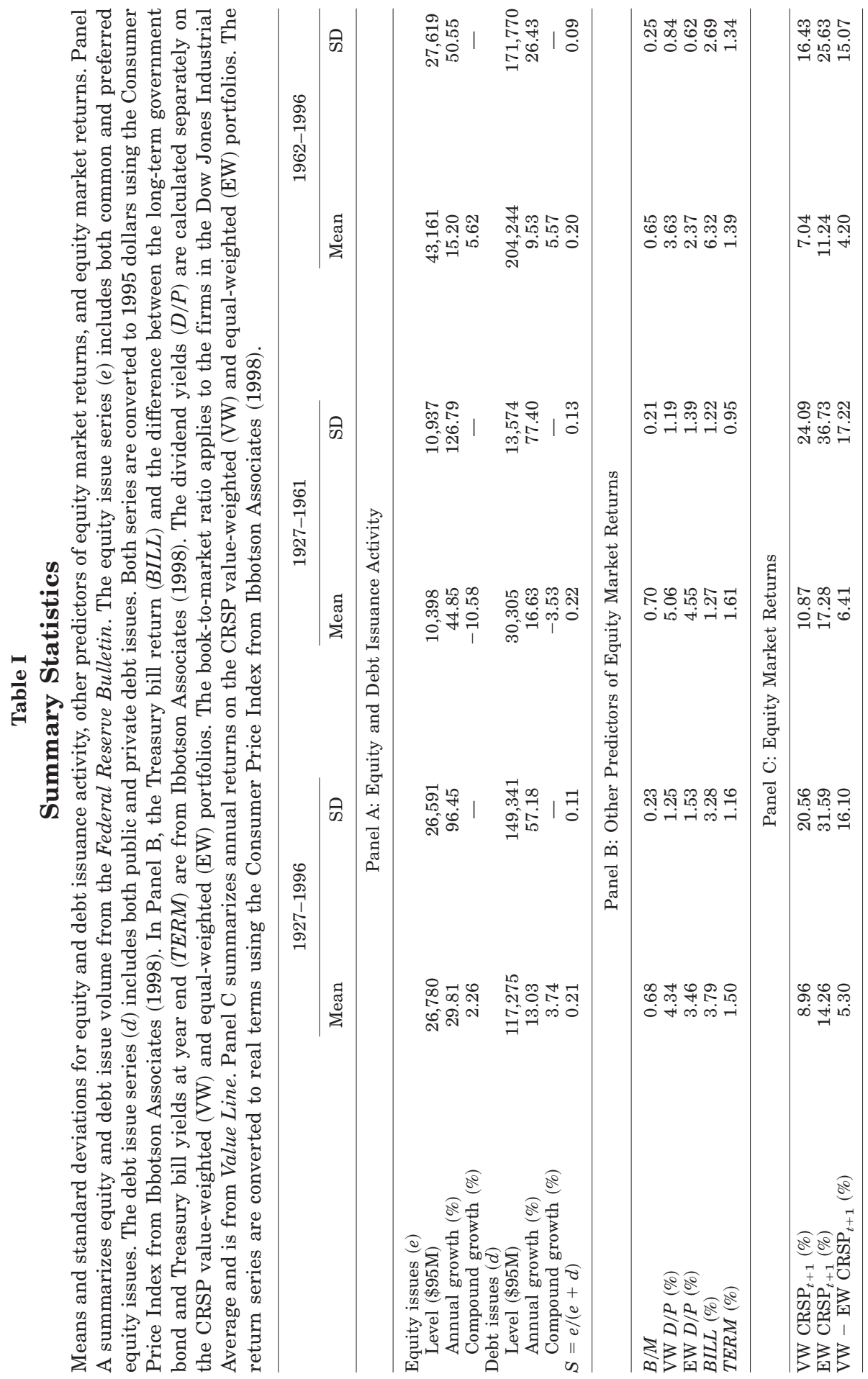


\section{Relatively Hot Markets: The Share of Equity in Total New Issues}

We scale equity issues $(e)$ by the sum of equity and debt issues $(e+d)$. The gross equity and debt issue quantities do not net out repurchases and debt retirements, and the denominator does not include bank debt, internal finance, or finance raised in foreign markets. ${ }^{6}$ Despite these shortcomings, we believe that the share of equity in gross equity and debt issues is a reasonable reflection of how firms favor equity or debt over time. ${ }^{7}$

Figure 1C plots the equity share in new issues from 1927 to 1996, and Panel A of Table I shows some summary statistics. In a typical year, about 21 percent of new issues are equity. The average equity share was about 22 percent between 1927 and 1961 and 20 percent between 1962 and 1996. Due to the high volatility of the equity share in the Depression years, we examine its predictive ability in the full period and separately in the first and second halves of the sample.

Variation in the equity share series comes from both the equity and debt components. The unscaled equity series spikes in 1929, 1971, 1983, 1986, and 1993. Figure $1 \mathrm{C}$ shows that the equity market is "relatively hot" in 1929 , 1933, 1937, 1946, and 1983. Only two of these years overlap. Sometimes the equity market is hot but the debt market is even hotter, and sometimes the equity market is cold but the debt market is even colder. More recently, the debt market has been relatively hot-although equity issues have hit record levels and hot IPOs have grabbed headlines, debt issues have grown even faster, keeping the equity share low.

Finally, it is interesting to note that the equity share in new issues was near the middle of its historical range in 1996. The dividend yield and the book-to-market ratio, by contrast, were extraordinarily low in 1996 (Campbell and Shiller (1998)).

\section{Other Data}

We compare the equity share to other known predictors of market returns. The best-known predictors are the aggregate book-to-market ratio (Kothari and Shanken (1997), Pontiff and Schall (1998)) and the aggregate dividend yield (Campbell and Shiller (1988), Fama and French (1988a)). In addition, Fama and Schwert (1977) find that the short interest rate is a bearish predictor of nominal market returns, and Keim and Stambaugh (1986), among others, find that the slope of the yield curve is a bullish predictor.

\footnotetext{
${ }^{6}$ Between 1927 and 1950, the Bulletin subdivides equity and debt issues into "new" and "refunding," based upon the company's stated purpose for the issue. Refunding finance replaces retired debt or repurchased equity. Between 1927 and 1950, new and total debt issues have a correlation of 0.74 , and new and total equity issues have a correlation of 0.99 . This provides some comfort in using total issues as a proxy for net issues.

${ }^{7}$ Hickman (1953) studies the relative frequency of equity to debt offers in the 1900 to 1938 period, and Moore (1983) studies the 1946 to 1970 period.
} 
Panel B of Table I reports summary statistics for these variables. The Dow Jones Industrial Average (DJIA) book-to-market series is denoted by $B / M{ }^{8}$ The value-weighted dividend yield (VW $D / P$ ) and equal-weighted dividend yield (EW $D / P$ ) apply to the value-weighted and equal-weighted indices from the Center for Research on Security Prices (CRSP). The treasury bill return $(B I L L)$ and the difference between the long-term government bond and Treasury bill yields (TERM) are from Ibbotson Associates (1998).

Panel C of Table I reports summary statistics for the CRSP value-weighted and equal-weighted market indices for various periods. Equal-weighted returns have been higher on average, and more volatile, than value-weighted returns.

\section{The Equity Share as a Predictor of Stock Market Returns}

This section describes the predictive power of the equity share for market returns. First, we outline the direction and economic significance of the predictive power. Next, we compare the univariate predictive power of the dividend yield, the book-to-market ratio, and the equity share. Finally, we show that the equity share adds new explanatory power to these and other known predictors.

\section{A. Preliminary Analysis}

Stock market returns tend to be high following low equity share years and low following high equity share years. Figure 2 illustrates this. We divide the 70 sample years into quartiles according to the prior-year equity share. In the year after bottom-quartile equity share years (below 0.14), real value-weighted returns average 14 percent But in the year after top-quartile years (above 0.27), real value-weighted returns average -6 percent. As a group, firms lean toward equity just before the market declines.

For value-weighted returns, most of the action appears to be in this high quartile. For equal-weighted returns, however, there is action in both of the extreme quartiles. Equal-weighted market returns average 27 percent following bottom-quartile equity share years, versus -8 percent following topquartile equity share years.

\footnotetext{
${ }^{8}$ Kothari and Shanken (1997) and Pontiff and Schall (1998) measure annual returns starting at the end of March, to be sure that the book values in the book-to-market measure are available before the return period. The book values apply to prior December fiscal year-ends, at the latest. For simplicity, we assume that the book values are known at the beginning of the year. This allows us to use the annual issues data reported in the Federal Reserve Bulletin and the calendar year returns used by most prior authors.
} 


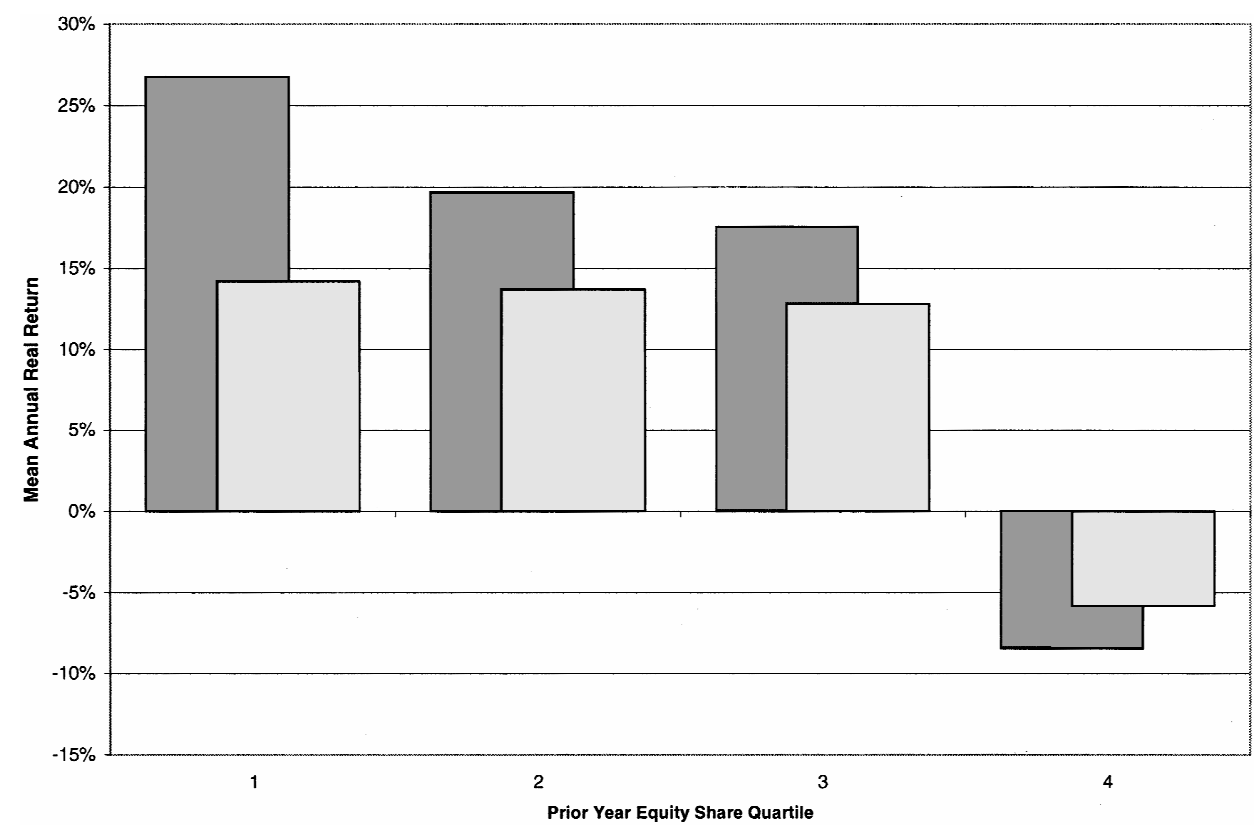

Figure 2. Mean equity returns by prior-year equity share in new issues, 1928-1997. Mean annual real returns on the CRSP value-weighted (light) and equal-weighted (solid) indexes by quartile of the prior-year share of equity issues in total equity and debt issues. Real returns are created using the Consumer Price Index from Ibbotson Associates (1998).

Figures $3 \mathrm{~A}$ and $3 \mathrm{~B}$ split the sample into halves. Figure $3 \mathrm{~A}$ shows the average equal-weighted and value-weighted return for the year before a low equity share year and the five years after, whereas Figure $3 \mathrm{~B}$ plots the same results around high equity share years. These figures reveal two interesting facts. First, the equity share is related to past returns. Figure 3A shows that firms lean away from equity after a year of low market returns, and Figure 3B shows that firms lean toward equity after a year of high returns. This confirms firm-level findings by Marsh (1982) and aggregate results by Choe, Masulis, and Nanda (1993). Second, the equity share's predictive power continues into the second year. Returns are high in each of the two years following a low equity share year and low in each of the two years following a high equity share year.

Table II tabulates the data in Figure 3 more formally. We compare the mean returns in the 10 years surrounding a low equity share year to the mean returns in the 10 years surrounding a high equity share year. The table confirms that firms lean toward equity after one year of high returns and before two years of low returns. As suggested by Figure 2, most of these contrasts are even larger when comparing top-quartile and bottom-quartile years instead of tophalf and bottom-half years. 
PANEL A. Mean returns on the VW CRSP (light) and EW (solid) CRSP indexes around low equity share years.

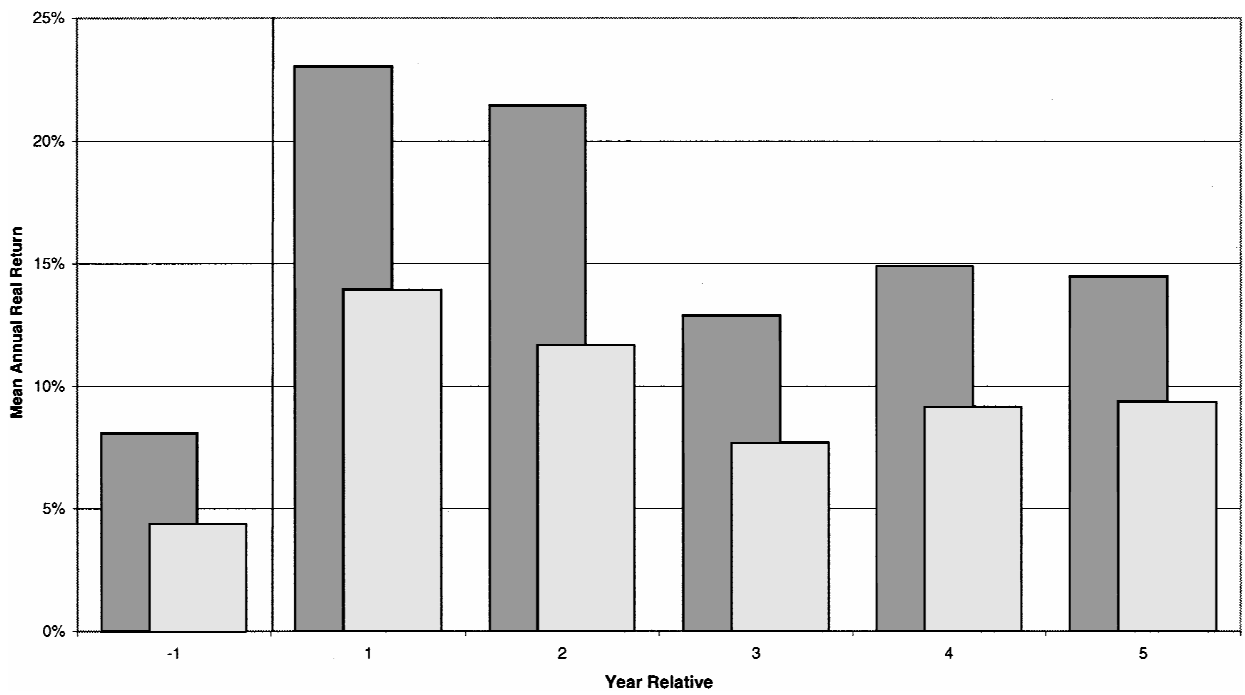

PANEL B. Mean returns on the VW CRSP (light) and EW (solid) CRSP indexes around high equity share years.

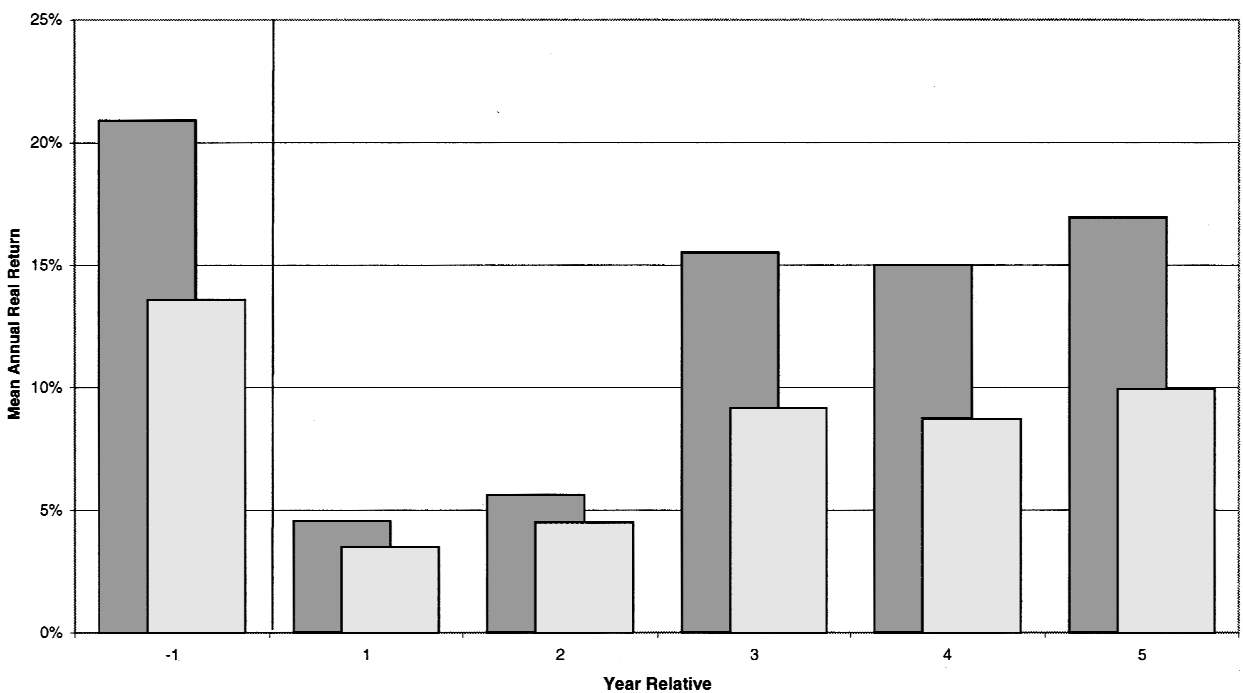

Figure 3. Mean past and future equity returns by equity share in new issues, 19281997. Figure $3 \mathrm{~A}$ plots mean past and future real annual returns on the CRSP value-weighted (light) and equal-weighted (solid) indexes for below-median equity share years. Figure 3B plots mean returns around above-median equity share years. Real returns are created using the Consumer Price Index from Ibbotson Associates (1998). 


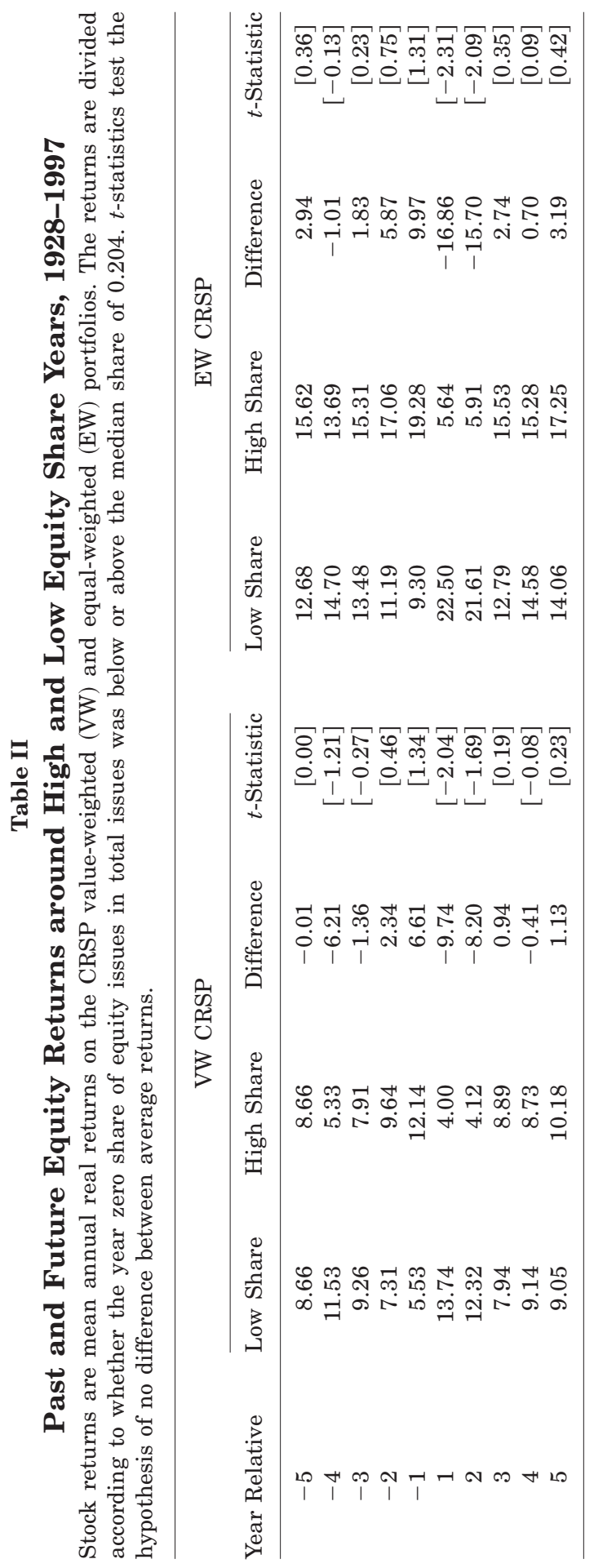




\section{B. Univariate Regressions}

In this subsection we compare the univariate predictive power of the dividend yield, the book-to-market ratio, and the equity share for equity market returns. Table III presents OLS regressions of one-year-ahead stock returns $\left(R_{E}\right)$ on these predictors $(X)$ :

$$
R_{E t}=a+b X_{t-1}+u_{t}
$$

The predictor variables are standardized so that the coefficients are comparable - a one standard deviation increase in $X$ predicts $b$ percent higher returns. ${ }^{9}$

We estimate equation (1) over the full sample period and over the first and second halves. Panel A reports estimates for the full period. The adjusted $R^{2}$ for the equity share is 0.12 for value-weighted returns and 0.16 for equalweighted returns. A one standard deviation increase in the equity share $(0.11)$ reduces average value-weighted returns by about 7 percent. For equalweighted returns, the effect is larger. In the full period, the book-to-market ratio $(B / M)$ does about as well as the equity share in predicting equalweighted returns but not nearly as well in predicting value-weighted returns. As a consequence, $B / M$ is best at predicting a measure of small stock returns, the difference between the equal-weighted and value-weighted returns. The dividend-to-price ratio is marginally significant for both equalweighted and value-weighted returns but is not as strong as the equity share. In the full sample, the equity share is the best single explanatory variable for both equal-weighted and value-weighted returns.

Panel $\mathrm{B}$ and Panel $\mathrm{C}$ confirm that each of the variables has some predictive power within certain subperiods, with exceptions: the dividend yield $(D / P)$ does not predict the first half equal-weighted returns, and $B / M$ does not predict the second half value-weighted returns. The coefficients on $D / P$ and $B / M$ also tend to vary dramatically across the two periods. In contrast, the equity share has roughly the same economic and statistical significance in both periods.

We have also split the sample by prewar and postwar subperiods to examine the robustness of the equity share's performance in the volatile Depression years. We find it is statistically significant and of similar magnitude across these subperiods also. For VW returns, the coefficient is -6.70 ( $t=$ $-2.70)$ using 1928 to 1945 returns and $-8.96(t=-2.61)$ using the 1946 to 1997 returns. For EW returns, the coefficient is $-13.21(t=-2.73)$ using 1928 to 1945 returns and $-13.06(t=-2.60)$ using the 1946 to 1997 returns.

\footnotetext{
${ }^{9}$ If predictability could reflect inefficiency, it is inaccurate to state that $X$ captures variation in "expected returns." One needs to define who is doing the expecting. It certainly would not be the investors holding long positions during a period of predictably low or negative returns. We think it is better to take the more agnostic view that $X$ reflects in-sample predictability, given the model rather than the potentially misleading phrase, "expected returns."
} 


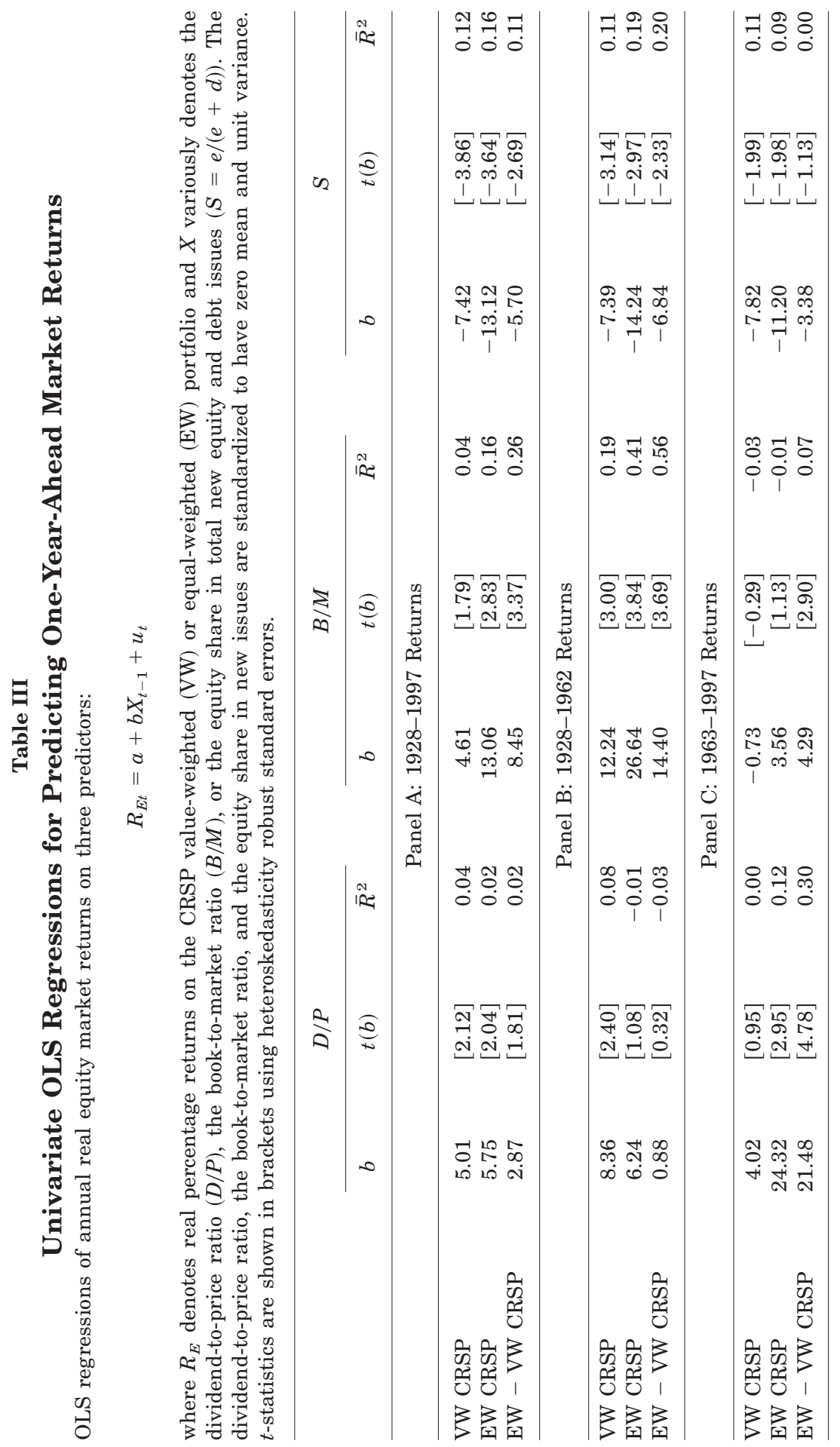


In Appendix A, we show that netting out repurchases, or making other allowances for junk and convertible debt or utilities issues, is of little consequence to the univariate results. The resulting series tend to be highly correlated with our unadjusted equity share series, and the predictive power is essentially the same.

On a statistical point, it has been noted that the $D / P$ and $B / M$ coefficients are subject to an upward small-sample bias. ${ }^{10}$ Nelson and Kim (1993) show this in a simple system:

$$
\begin{gathered}
R_{E t}=a+b X_{t-1}+u_{t}, \\
X_{t}=c+d X_{t-1}+v_{t} .
\end{gathered}
$$

In this setup, the bias in estimating the OLS coefficient for $b$ depends on the contemporaneous covariance between the two residuals, $u$ and $v$, and the bias in the OLS estimate of $d$ (Stambaugh (2000)):

$$
E[\hat{b}-b]=\frac{\sigma_{u v}}{\sigma_{v}^{2}} E[\hat{d}-d]
$$

where the hats denote OLS estimates.

For the scaled-price variables, one expects the residuals of equation (3) to covary negatively with the residuals from equation (2). For example, an unusually high return increases the denominator of the scaled-price predictor. In addition, the bias in estimating $d$ is also negative (Kendall (1954)). From equation (4), the OLS estimate of $b$ is biased upward for $D / P$ and $B / M$. Therefore Table III overstates the economic significance of these predictors.

We do not expect the equity share coefficient to be similarly biased because it is not highly autocorrelated and it is not a scaled-price variable. To verify this, we calculated the empirical correlation for the OLS residuals for equations (2) and (3) for each of the three predictor variables. The results are presented in Table IV. For the book-to-market ratio and dividend yield, we replicate the findings of Kothari and Shanken (1997). There is a significant negative contemporaneous correlation between the residuals ranging from -0.7 to -0.9 . The equity share residuals, by contrast, show little correlation. Table IV also reports bias-adjusted estimators based on Kendall's correction for autocorrelated regressors, as suggested by Kothari and Shanken. The scaled-price variables' bias-adjusted coefficient estimates are 15 percent to 45 percent smaller than their OLS estimates, but the adjustment makes almost no difference for the equity share.

\footnotetext{
${ }^{10}$ Kothari and Shanken (1997) discuss this issue in more detail.
} 


\section{Table IV}

\section{Correlation of the Residuals for the Univariate Market} Regression and the Predictor Autoregression, 1928-1997

OLS regressions of annual real equity market returns and autoregressions for three predictors:

$$
\begin{gathered}
R_{E t}=a+b X_{t-1}+u_{t} \\
X_{t}=c+d X_{t-1}+v_{t}
\end{gathered}
$$

where $R_{E}$ denotes real percentage returns on the CRSP value-weighted (VW) or equal-weighted (EW) portfolio and $X$ variously denotes the dividend-to-price ratio $(D / P)$, the book-to-market ratio $(B / M)$, or the equity share in total new equity and debt issues $(S=e /(e+d))$. Panel A shows OLS estimates of $a$ and $b$. Panel B shows estimates of $c$ and $d$. Panel $\mathrm{C}$ shows estimates of the correlation between the two residuals, $u$ and $v$, and tests its significance level against a null hypothesis of zero correlation. In addition, we calculate bias-adjusted estimates of $b$ following Kothari and Shanken (1997, equation (4)). The dividend-to-price ratio, the book-tomarket ratio, and the equity share are standardized to have zero mean and unit variance.

\begin{tabular}{|c|c|c|c|c|c|c|}
\hline & \multicolumn{2}{|c|}{$D / P$} & \multicolumn{2}{|c|}{$B / M$} & \multicolumn{2}{|c|}{$S$} \\
\hline & VW CRSP & EW CRSP & VW CRSP & EW CRSP & VW CRSP & EW CRSP \\
\hline \multicolumn{7}{|c|}{ Panel A: Market Return OLS regression } \\
\hline Intercept $a$ & $\begin{array}{c}8.72 \\
{[3.65]}\end{array}$ & $\begin{array}{l}13.96 \\
{[3.75]}\end{array}$ & $\begin{array}{c}8.87 \\
{[3.70]}\end{array}$ & $\begin{array}{l}14.07 \\
{[4.08]}\end{array}$ & $\begin{array}{c}8.93 \\
{[3.89]}\end{array}$ & $\begin{array}{l}14.17 \\
{[4.10]}\end{array}$ \\
\hline Slope $b$ & $\begin{array}{c}5.01 \\
{[2.12]}\end{array}$ & $\begin{array}{c}5.75 \\
{[2.04]}\end{array}$ & $\begin{array}{c}4.61 \\
{[1.79]}\end{array}$ & $\begin{array}{l}13.06 \\
{[2.83]}\end{array}$ & $\begin{array}{c}-7.42 \\
{[-3.86]}\end{array}$ & $\begin{array}{l}-13.12 \\
{[-3.64]}\end{array}$ \\
\hline $\bar{R}^{2}$ & 0.04 & 0.02 & 0.04 & 0.16 & 0.12 & 0.16 \\
\hline \multicolumn{7}{|c|}{ Panel B: Predictor OLS Autoregression } \\
\hline Intercept $c$ & $\begin{array}{c}-3.20 \\
{[-0.48]}\end{array}$ & $\begin{array}{c}-2.26 \\
{[-0.42]}\end{array}$ & & $\begin{array}{c}-0.39 \\
{[-0.05]}\end{array}$ & & $\begin{array}{c}-1.07 \\
{[-0.10]}\end{array}$ \\
\hline Slope $d$ & $\begin{array}{c}0.85 \\
{[9.12]}\end{array}$ & $\begin{array}{c}0.91 \\
{[17.44]}\end{array}$ & & $\begin{array}{c}0.78 \\
{[7.17]}\end{array}$ & & $\begin{array}{c}0.45 \\
{[2.41]}\end{array}$ \\
\hline $\bar{R}^{2}$ & 0.68 & 0.80 & & 0.57 & & 0.19 \\
\hline \multicolumn{7}{|c|}{ Panel C: Bias-Adjusted Estimate } \\
\hline$\rho_{u v}$ & -0.70 & -0.67 & -0.87 & -0.78 & 0.11 & 0.11 \\
\hline$p$-value & 0.00 & 0.00 & 0.00 & 0.00 & 0.37 & 0.36 \\
\hline$\sigma_{u v} / \sigma_{v}^{2}$ & -24.46 & -45.82 & -26.61 & -34.43 & 2.33 & 3.54 \\
\hline Bias adjusted $b$ & 3.71 & 3.20 & 3.28 & 11.35 & -7.34 & -13.00 \\
\hline$N$ & 70 & 70 & 70 & 70 & 70 & 70 \\
\hline
\end{tabular}
$t$-statistics are shown in brackets using heteroskedasticity robust standard errors.

\section{Multivariate Regressions}

In this section we examine the incremental power of the equity share over other predictors of aggregate returns. Table V presents OLS regressions of equity market index returns $\left(R_{E}\right)$ on past returns, the Treasury bill return 
Table V

\section{Multivariate OLS Regressions for Predicting One-Year-Ahead Market Returns}

OLS regressions of annual real equity market returns on multiple predictors:

$$
R_{E t}=a+b_{1} R_{E t-1}+b_{2} B I L L_{t-1}+b_{3} T E R M_{t-1}+b_{4} D / P_{t-1}+b_{5} B / M_{t-1}+b_{6} S_{t-1}+u_{t}
$$

where $R_{E}$ denotes real percentage returns on the CRSP value-weighted (VW) or equal-weighted (EW) portfolio, BILL denotes the return on Treasury bills, TERM denotes the yield premium of long-term government bonds over treasuries, $D / P$ denotes the dividend-to-price ratio, $B / M$ denotes the book-to-market ratio, and $S$ denotes the equity share in new issues. The dividend-toprice ratio, the book-to-market ratio, and the equity share are standardized to have zero mean and unit variance. $t$-statistics are shown in brackets using heteroskedasticity robust standard errors.

\begin{tabular}{|c|c|c|c|c|c|c|}
\hline & \multicolumn{2}{|c|}{ 1928-1997 Returns } & \multicolumn{2}{|c|}{ 1928-1962 Returns } & \multicolumn{2}{|c|}{ 1963-1997 Returns } \\
\hline & VW CRSP & EW CRSP & VW CRSP & EW CRSP & VW CRSP & EW CRSP \\
\hline \multirow[t]{2}{*}{ Intercept } & 6.95 & 21.72 & 14.33 & 21.71 & 11.50 & 19.23 \\
\hline & {$[1.13]$} & [1.68] & {$[0.53]$} & {$[0.76]$} & {$[0.78]$} & {$[1.16]$} \\
\hline \multirow[t]{2}{*}{$R_{E}$} & 0.05 & 0.08 & 0.27 & 0.20 & -0.20 & -0.09 \\
\hline & {$[0.39]$} & {$[0.82]$} & {$[1.12]$} & {$[1.09]$} & {$[-1.01]$} & {$[-0.68]$} \\
\hline \multirow[t]{2}{*}{$B I L L$} & 0.71 & -0.85 & 4.96 & 9.60 & 0.66 & 4.20 \\
\hline & [0.89] & {$[-0.47]$} & {$[0.75]$} & [1.28] & {$[0.40]$} & {$[1.46]$} \\
\hline \multirow[t]{2}{*}{ TERM } & -0.86 & -3.66 & -7.98 & -10.86 & 0.15 & 6.09 \\
\hline & {$[-0.41]$} & {$[-0.96]$} & {$[-0.70]$} & {$[-0.84]$} & {$[0.08]$} & {$[1.45]$} \\
\hline \multirow[t]{2}{*}{$D / P$} & 4.26 & -1.58 & -4.37 & -9.17 & 14.51 & 63.21 \\
\hline & {$[1.13]$} & {$[-0.27]$} & {$[-0.51]$} & {$[-1.55]$} & {$[1.43]$} & {$[2.41]$} \\
\hline \multirow[t]{2}{*}{$B / M$} & 1.51 & 13.50 & 19.59 & 34.10 & -7.30 & -14.30 \\
\hline & {$[0.38]$} & [2.38] & [1.99] & [6.34] & {$[-1.29]$} & {$[-1.47]$} \\
\hline$S$ & -7.88 & -13.17 & -8.84 & -14.34 & -8.27 & -13.63 \\
\hline 1 & {$[-3.97]$} & {$[-3.77]$} & {$[-1.94]$} & {$[-2.21]$} & {$[-2.13]$} & {$[-2.48]$} \\
\hline $\bar{R}^{2}$ & 0.12 & 0.28 & 0.27 & 0.51 & 0.12 & 0.29 \\
\hline$N$ & 70 & 70 & 35 & 35 & 35 & 35 \\
\hline
\end{tabular}

$(B I L L)$, the term premium $(T E R M)$, the dividend yield $(D / P)$, the book-tomarket ratio $(B / M)$, and the equity share $(S)$ :

$$
\begin{aligned}
R_{E t}= & a+b_{1} R_{E t-1}+b_{2} B I L L_{t-1}+b_{3} T_{E R M_{t-1}+b_{4} D / P_{t-1}+b_{5} B / M_{t-1}} \\
& +b_{6} S_{t-1}+u_{t} .
\end{aligned}
$$

Fama and French (1988b) and Poterba and Summers (1988) find that market returns have a small negative autocorrelation at one-year horizons, so we include the lagged market return. The last three predictor variables are again standardized to have zero mean and unit variance. We estimate equation (5) over the full sample period and over the first and second halves. 
Table $\mathrm{V}$ shows that, across different sample periods and market return indices, the equity share is the most consistently significant predictive variable. For the entire period, the equity share is significant at the one percent level for both value-weighted and equal-weighted returns. Neither the dividend yield nor the book-to-market ratio is significant for value-weighted returns. The book-to-market ratio's strong first half performance is enough to make it significant for equal-weighted returns over the full period, but it does not help to predict value-weighted returns. In fact, both the $B / M$ and $D / P$ coefficients change sign from the first half to the second half. Pontiff and Schall (1998) discuss the erratic predictive ability of $B / M$ in more detail. There does not appear to be any mean reversion (conditional on the other variables) at the one-year horizon. ${ }^{11}$ Finally, the bond market variables we consider are weak predictors of real returns. ${ }^{12}$

The equity share is not significantly correlated with either the dividend yield or the book-to-market ratio. Therefore its predictive power is complementary. However, the scaled-price variables are themselves highly correlated, as Kothari and Shanken (1997) show. In our sample the correlation between VW $D / P(\mathrm{EW} D / P)$ and $B / M$ is $0.68(0.43)$ and is statistically significant. Because book value and dividends are both highly persistent, most of the variation in the scaled-price variables comes from changes in their common denominator.

One implication of this high correlation is that the parameter instability of these coefficients may in part reflect collinearity. A second implication is that looking at the scaled-price variables separately may understate their combined significance. To evaluate the latter possibility, we perform an $F$-test of the hypothesis that $D / P$ and $B / M$ together have no predictive power. For the full sample, we can almost reject this hypothesis at the five percent level for value-weighted returns $(p$-value $=0.053)$. This hypothesis is more strongly rejected for equal-weighted returns; in the full sample, scaled-price variables do have some joint explanatory power for equalweighted returns, even after the equity share and other conditioning variables are included.

\section{Interpreting the Results: Efficient Market or Market Timing?}

Unless we agree that rational expected returns are constant, the fact that the equity share predicts returns does not by itself demonstrate inefficiency. In this section we consider three ways in which the equity share in new

\footnotetext{
11 The five-year average equity share does not do well at predicting average returns over the next five years (unreported). This highlights the fact that the equity share's predictive power comes at a much shorter horizon than the mean reversion documented in Fama and French (1988b) and Poterba and Summers (1988).

12 The deviation of the Treasury yield from its six-month moving average produces a stronger negative coefficient than that which we report for BILL. Use of this alternative short-term rate indicator does not change the predictive power of the equity share, however.
} 
issues could be negatively related to rationally time-varying returns. Finding that none is supported by the data, we turn to the market timing explanation.

\section{A. Modigliani and Miller Effect}

In the framework of Modigliani and Miller (1958), an increase in leverage causes an increase in the expected return on equity. Because aggregate leverage tends to increase when the equity share is low, this effect produces a negative relationship between the equity share and future returns, as we found empirically.

However, the empirical equity share coefficient is much too large to be explained by this effect. In particular, it is straightforward to show that the first-order effect of new issues, as measured by the equity share, on expected equity returns is

$$
\frac{d E\left[R_{E}\right]}{d S}=\frac{-\alpha E\left[R_{A}-R_{D}\right]}{S^{2}}
$$

where $\alpha$ is the ratio of new equity issues to the aggregate value of equity including the new issues, $E\left[R_{A}-R_{D}\right]$ is the expected excess return of total corporate assets over corporate debt, and $S$ is the equity share in new issues. ${ }^{13}$

We can use historical averages to measure these quantities and then compare the predicted theoretical effect of the equity share with the actual coefficient in Table III and Table V. From 1927 to 1996, the average ratio of new equity issues to the aggregate market value of equity was 1.7 percent. Over the same period, the average excess large company stock return over corporate debt was approximately 6.5 percent, as reported in Ibbotson Associates (1998). Because expected equity returns must be higher than expected asset returns, this represents an upper bound for the excess return of assets over debt. Finally, the average equity share in new issues was 0.21.

Plugging these values into equation (6) gives a bound of -2.5 . To compare this with the standardized empirical results, we multiply by 0.11 , the standard deviation of the equity share. This yields a predicted theoretical equity share coefficient of -0.28 , as compared to actual coefficients between -7.42 (from the univariate analysis) and -7.88 (from the multivariate analysis). This analysis indicates that the leverage risk effect explains less than onetwentieth of the equity share's actual effect.

\footnotetext{
13 The first step is to write postissue leverage as a weighted average of the leverage excluding new issues and the leverage of the new issues themselves. The second step is to rewrite the leverage of new issues in terms of the equity share. The third step is to substitute the resulting expression for postissue leverage $L$ into the Modigliani and Miller arbitrage condition $E\left[R_{E}\right]=$ $E\left[R_{A}\right]+L\left[R_{A}-R_{D}\right]$. The final step is to differentiate $E\left[R_{E}\right]$ with respect to $S$. We ignore the derivative of $R_{D}$ with respect to $S$ and therefore derive an upper bound impact of the equity share on returns. The true impact is closer to zero.
} 


\section{B. Investment}

The equity share could be negatively related to rationally time-varying future returns through investment. For example, if the rational discount rate falls, firms will increase investment, and the equity share may increase incidentally if firms follow a pecking-order policy. Myers and Majluf (1984) show that when managers have information that investors do not have, external finance is more costly than internal finance, and equity is more costly than debt. If in addition firms have a fixed debt capacity, the ratio of equity to external finance will increase with financing requirements, that is, the equity share rises with investment.

This story makes the additional prediction that the level of investment forecasts rational variation in returns. Importantly, as we show using a model of investment and financing based on Stein (1996), optimal investment need not depend on variation in returns due to mispricing. We develop these theoretical predictions and then check whether the level of aggregate investment is actually negatively related to subsequent returns. Because it is not, we do not advocate explanation for the equity share's predictive power based on a link through investment to a time-varying discount rate.

Stein argues that there are three factors that determine the level and composition of securities issues: the value of the investment opportunity itself; the market timing gain (if any) associated with new issues; and the cost of deviating from optimal capital structure. In a simple reduced form, these factors may be summarized in the following managerial decision problem for a representative firm:

$$
\max _{S, I} f(I)-\left(1+E\left[R_{A}\right]\right) I-\delta S I-i(S I)-z((S-\bar{S}) I)
$$

The manager chooses the equity share in new issues, $S$, and the level of total equity and debt issues, $I$. The product $S I$ therefore denotes the level of equity issues ( $e$ elsewhere in the paper), and $I-S I$ denotes the level of debt issues ( $d$ elsewhere).

The project's expected payoff is $f(\cdot)$, which is increasing and concave. The rational expected return on financial assets is $E\left[R_{A}\right]$, which may vary from period to period. The third and fourth terms represent the market timing gains associated with equity issues. $\delta$ is the irrational component of expected equity returns and also may vary from period to period. (When equity is overpriced, $\delta$ is negative.) The announcement effect associated with equity issues and repurchases, $i(\cdot)$, is represented by a cost function that is $\mathrm{U}$-shaped around zero. Thus, the bigger is the announced equity issue or repurchase, the more suspicious new shareholders are that they are being exploited, and the more they revalue the firm to reduce the scope for market timing. The cost of deviating from optimal capital structure is given by the final term, $z(\cdot)$, which is also U-shaped around zero. We assume the firm's optimal cap- 
ital structure would be maintained if the manager set the equity share at $\bar{S}$. Above $\bar{S}$, agency costs and lost tax shields exceed reductions in expected financial distress costs. Below $\bar{S}$, the opposite is true. ${ }^{14}$

The comparative statics of this program show how investment and the equity share respond to the parameters $E\left[R_{A}\right]$ and $\delta$. Note this model does not explain how or why the market may be mispriced in the first place. Instead, it guides a search for comparative statics predictions that may help to discriminate between efficient market and inefficient market explanations for our main results, a relationship between financing activity and returns.

We would ideally like to compute comparative statics with respect to $E\left[R_{E}\right]$ (the rational expected return on equity) and $\delta$ because full-information expected equity returns are $E\left[R_{E}\right]+\delta$. In a rational model of returns, there is a direct link between $E\left[R_{E}\right]$ and $E\left[R_{A}\right]$ through a Modigliani and Miller relationship. Of course, equation (6) shows that $E\left[R_{E}\right]$ also depends on the change in leverage induced by new issues, but we just found the effect to be negligible.

In Panel A of Table VI, we report comparative statics results for the efficient markets case: $E\left[R_{A}\right]$ varies over time, but $\delta$ is always zero. The calculations are in Appendix B. The comparative statics turn out to be sensitive to whether information costs, $i(\cdot)$, or suboptimal leverage costs, $z(\cdot)$, dominate, so we report results for both cases. In the first case, information costs are assumed to dominate. When required returns $E\left[R_{A}\right]$ increase, for instance, investment falls. Because the announcement effect is increasing in the dollar value of equity issues $(S I)$, a lower level of investment allows a larger share of equity issues. Thus, $S$ rises with $E\left[R_{A}\right]$.

In the second case, the cost of deviating from optimal leverage is assumed to dominate. Because there is an announcement effect, the equity share will always be below the share that keeps leverage at the optimum, $\bar{S}$. As before, when required returns increase, investment falls. Now, because the cost of deviating from optimal leverage is increasing in the dollar value of equity issues, lower investment allows an even smaller equity share, so $S$ falls.

The second case demonstrates how, in some circumstances, a high equity share could forecast low equity returns even in the absence of a timing motive. But an unambiguous prediction of all efficient markets cases is that there should be a strong negative relationship between investment and subsequent returns. This is true regardless of the structure of information and suboptimal leverage costs.

In Panel $\mathrm{B}$, we summarize predictions of the polar inefficient markets case: $E\left[R_{A}\right]$ is constant, but $\delta$ varies. The results are quite different from the efficient markets case. If information costs dominate, mispricing has little

\footnotetext{
${ }^{14}$ See Stein's paper (1996) for more discussion of the structure of equation (7). Despite the simplifications apparent in this stylized setup, some issues still have to be ignored to keep the analysis tractable. For one, the model assumes no internal finance is available; investment equals the total raised through new issues. The model also ignores the option to delay investment.
} 


\section{Table VI}

\section{Comparative Statics of an Investment and Financing Model}

This table summarizes comparative statics predictions made by a representative-firm security issue model based on Stein (1996):

$$
\max _{S, I} f(I)-\left(1+E\left[R_{A}\right]\right) I-\delta S I-i(S I)-z((S-\bar{S}) I) .
$$

The manager chooses the equity share $(S=e / e+d)$ and the level of investment $(I=e+d)$ to maximize an objective that depends on the project's expected payoff $(f(\cdot))$, the rational cost of capital $\left(E\left[R_{A}\right]\right)$, the irrational component of equity returns $(\delta)$, the information cost (announcement effect) of equity issues $(i(\cdot))$, and the cost of deviating from optimal capital structure $(z(\cdot)) . f(\cdot)$ is increasing and concave, and $i(\cdot)$ and $z(\cdot)$ are $\mathrm{U}$-shaped around zero. In Panel A, variation in full-information expected equity returns is entirely rational. In Panel B, equity mispricing $(\delta)$ drives full-information expected equity returns. The relationships are derived in Appendix B.

\begin{tabular}{lcc}
\hline & \multicolumn{2}{c}{$\begin{array}{c}\text { Response to Determinants of } \\
\text { Cquity Returns }\left(E\left[R_{A}\right] \text { and } \delta\right)\end{array}$} \\
\cline { 2 - 3 } & $\begin{array}{c}\text { Investment } \\
(I)\end{array}$ & $\begin{array}{c}\text { Equity Share } \\
(S)\end{array}$ \\
\hline Panel A: Efficient Market $\left(E\left[R_{A}\right]\right.$ varies rationally, $\left.\delta=0\right)$ & \\
\hline $\begin{array}{l}\text { Information costs }(i) \text { dominate suboptimal leverage costs }(z) \\
\text { Suboptimal leverage costs dominate information costs }\end{array}$ & - & + \\
\hline Panel B: Inefficient Market $\left(E\left[R_{A}\right]\right.$ constant, $\delta$ varies $)$ & - \\
\hline Information costs dominate suboptimal leverage costs & 0 & - \\
Suboptimal leverage costs dominate information costs & - & $?$ \\
\hline
\end{tabular}

effect on investment. Investment is primarily determined by $E\left[R_{A}\right]$, which is assumed roughly constant, so the upshot is that one observes no correlation between investment and subsequent equity returns. And now timing motives are apparent: the equity share rises when equity is overvalued, that is, when $\delta$ is negative.

If suboptimal leverage costs dominate, on the other hand, investment and financing are not separable. In the absence of mispricing, the equity share would be set at $\bar{S}$. But maintaining this ratio imposes costs and benefits through $\delta$. The negative relationship between investment and returns reappears, but the relationship between the equity share and returns can go either way, depending on the degree of mispricing.

The takeaway is that investment should be strongly negatively related to rational, predictable variation in returns but need not be related to returns driven by mispricing. To evaluate the empirical link between investment and subsequent returns, we gather net nonresidential fixed capital stock 
data from the Survey of Current Business, United States Department of Commerce, August 1994 issue. We define investment as the change in this capital stock. ${ }^{15}$

We find a positive but statistically insignificant relationship between the level of investment and the equity share, which is suggestive of peckingorder financing. The relationship between aggregate investment and subsequent stock returns is also weak. Between 1928 and 1995, the correlation between aggregate investment (the ratio of investment to the capital stock) and one-year-ahead value-weighted returns is -0.09 , not significantly different from zero. Table VII presents regressions of returns on lagged investment. Column (1) shows that investment is negatively but not strongly associated with future value-weighted returns.

Column (2) shows that how investment is financed is much more important than the level of investment itself. The three independent variables are new equity over the capital stock, new debt over capital stock, and residual investment (internally financed investment) over the capital stock. In frictionless capital markets, when the level of investment is the critical predictor, the three separate coefficients need not differ. This restriction is rejected at the one percent level of significance. (For value-weighted returns, $F_{2,63}$ is 4.99 and the $p$-value is 0.0098 , and for equal weighted returns, $F_{2,63}$ is 6.03 and the $p$-value is 0.0040.) Column (3) shows that the predictive power of the equity share is unchanged when we control for the level of investment.

An alternative measure of corporate investment is the sum of new equity and new debt issues-the denominator of the equity share. In column (4), we replace investment with total new issues scaled by the lagged equity market capitalization from CRSP $(M V E)$. The results are similar to those of column (3). We also tried using just the level of equity issues scaled by $M V E$. This variable is significantly negative when included alone but becomes insignificant when included alongside the equity share, which remains strongly significant. Columns (5) through (8) present similar results for equal-weighted returns.

In sum, we do not find evidence that our results for the equity share are driven by the level of total investment, the level of total new issues, or the level of equity issues. Instead, the way investment is financed (in particular, as measured by the equity share) appears to contain the most information for future returns. In terms of the model, our joint results for the equity share and investment are most consistent with the predictions of an inefficient markets case-the first case in Table VI, Panel B-where announcement costs of equity issues dominate capital structure costs.

\footnotetext{
15 Note that closed-end fund issues do not increase real investment. Therefore the efficient market version of the model is not able to explain why this component of the equity share would predict equity returns.
} 


\section{Table VII}

\section{New Issues, Investment, and Equity Market Returns}

OLS regressions of annual real equity market returns on the level and composition of investment:

$$
\begin{aligned}
R_{E t}= & a+b_{1}(I / K)_{t-1}+b_{2}(e / K)_{t-1}+b_{3}(d / K)_{t-1}+b_{4}[(I-e-d) / K]_{t-1}+b_{5}[(e+d) / M V E]_{t-1} \\
& +b_{6} S_{t-1}+u_{t}
\end{aligned}
$$

where $R_{E}$ denotes real percentage returns on the CRSP value-weighted (VW) or equal-weighted (EW) portfolio, $I / K$ denotes aggregate investment relative to the aggregate capital stock, $e / K$ denotes new equity issues relative to the capital stock, $d / K$ denotes new debt issues relative to the capital stock, $[(I-e-d) / K]$ denotes investment from sources other than new issues relative to the capital stock, $(e+d) / M V E$ denotes total issues relative to aggregate market capitalization, and $S$ denotes the equity share in total new equity and debt issues. Investment is defined as the change in the net nonresidential fixed capital stock, which is from the Survey of Current Business, United States Department of Commerce, August 1994 issue. MVE is calculated as the total market capitalization from CRSP. The equity share in new issues $(S)$ and $(e+$ d)/MVE are standardized to have zero mean and unit variance. $t$-statistics are shown in brack-

\begin{tabular}{|c|c|c|c|c|c|c|c|c|}
\hline & \multicolumn{4}{|c|}{ VW CRSP } & \multicolumn{4}{|c|}{ EW CRSP } \\
\hline & (1) & (2) & (3) & (4) & (5) & (6) & (7) & (8) \\
\hline Intercept & $\begin{array}{l}10.77 \\
{[2.37]}\end{array}$ & $\begin{array}{l}20.46 \\
{[3.90]}\end{array}$ & $\begin{array}{c}9.96 \\
{[2.52]}\end{array}$ & $\begin{array}{c}8.63 \\
{[3.72]}\end{array}$ & $\begin{array}{l}20.41 \\
{[2.53]}\end{array}$ & $\begin{array}{l}35.89 \\
{[3.60]}\end{array}$ & $\begin{array}{l}18.93 \\
{[2.78]}\end{array}$ & $\begin{array}{l}14.09 \\
{[4.09]}\end{array}$ \\
\hline$I / K$ & $\begin{array}{c}-0.43 \\
{[-0.88]}\end{array}$ & & $\begin{array}{c}-0.27 \\
{[-0.65]}\end{array}$ & & $\begin{array}{c}-1.05 \\
{[-1.16]}\end{array}$ & & $\begin{array}{c}-0.75 \\
{[-1.01]}\end{array}$ & \\
\hline$e / K$ & & $\begin{array}{c}-1.26 \\
{[-2.67]}\end{array}$ & & & & $\begin{array}{c}-2.53 \\
{[-2.67]}\end{array}$ & & \\
\hline$d / K$ & & $\begin{array}{c}-0.98 \\
{[-1.95]}\end{array}$ & & & & $\begin{array}{c}-1.88 \\
{[-1.93]}\end{array}$ & & \\
\hline$(I-e-d) / K$ & & $\begin{array}{l}-0.60 \\
{[-1.42]}\end{array}$ & & & & $\begin{array}{l}-1.33 \\
{[-1.61]}\end{array}$ & & \\
\hline$(e+d) / M V E$ & & & & $\begin{array}{c}-1.26 \\
{[-0.47]}\end{array}$ & & & & $\begin{array}{c}-6.47 \\
{[-1.60]}\end{array}$ \\
\hline$S$ & & & $\begin{array}{c}-6.86 \\
{[-3.60]}\end{array}$ & $\begin{array}{l}-7.23 \\
{[-3.65]}\end{array}$ & & & $\begin{array}{l}-12.52 \\
{[-3.81]}\end{array}$ & $\begin{array}{l}-12.28 \\
{[-3.41]}\end{array}$ \\
\hline $\bar{R}^{2}$ & 0.00 & 0.11 & 0.10 & 0.11 & 0.03 & 0.16 & 0.17 & 0.19 \\
\hline$N$ & 67 & 67 & 67 & 69 & 67 & 67 & 67 & 69 \\
\hline
\end{tabular}
ets using heteroskedasticity robust standard errors.

\section{Omitted Factors Driving Both Capital Structure Changes and Returns}

One generalization of the model might allow the ideal capital structure $\bar{S}$ to vary with $E\left[R_{A}\right]$, for example, through risk. Traditional theory points toward a positive, not negative, relationship between the equity share and future returns. That is, when expected returns go up with risk, the probability of financial distress for a given capital structure rises. And because 
tax schedules are convex, extra risk also causes the expected benefit of debt tax shields to fall. Given that the costs of leverage increase and the benefits fall, higher risk and returns demand more equity, not less.

More formally, a link between $\bar{S}$ and $E\left[R_{A}\right]$ does not change the comparative statics for the equity share presented in Panel A of Table VI, but the relationship between investment and $E\left[R_{A}\right]$ becomes indeterminate if $\bar{S}$ is negatively related to $E\left[R_{A}\right]$ (and suboptimal leverage costs dominate information costs). This represents an efficient market explanation that predicts both a negative relationship between the equity share and returns and no relationship between investment and returns, just as observed in the data.

Though possible in theory, a negative relationship between $\bar{S}$ and $E\left[R_{A}\right]$ seems unlikely. The opposite is much more plausible, as in the risk example. In any case, this explanation does offer a testable prediction: the equity share's predictive power should weaken or disappear after controlling for leverage, and leverage itself should be strongly related to returns (beyond the MM effect). ${ }^{16}$ Although we do not have data on optimal leverage, we do have book leverage data-the ratio of long-term debt to the sum of long-term debt and book equity-from the Internal Revenue Service's Statistics of Income: Corporation Income Tax Returns. We analyze these data in Table VIII.

Whatever theory might connect the two, future returns and book leverage are empirically unrelated. The coefficient in a regression of value-weighted returns on lagged book leverage shown in column (1) of Table VIII is not significantly different from zero. The relationship is stronger for market leverage, which uses the DJIA book-to-market ratio. In column (2), the coefficient has the predicted sign-higher leverage predicts higher future returns-and is statistically significant at the 10 percent level. Note, however, that this correlation includes the mechanical MM effect described previously and also the book-to-market ratio effect introduced by our capitalization method, in addition to any other impact.

Column (3) of Table VIII shows that capital structure is not empirically a mediator between the equity share and future returns. We regress valueweighted returns on the lagged market leverage ratio and the equity share. The statistical and economic significance of the equity share remains as strong here as in regressions that do not control for leverage. Columns (4), (5), and (6) show analogous results for equal-weighted returns. In these regressions also, the significance of market leverage is driven by the bookto-market capitalization effect. ${ }^{17}$ These results do not support the hypothesis that an omitted factor is driving both capital structure changes and returns.

\footnotetext{
${ }^{16}$ Note that closed-end fund issues do not change the aggregate leverage structure. Therefore the capital structure explanation considered here does not address why this component of the equity share would predict equity returns.

${ }^{17}$ Neither leverage nor the equity share predicts risk, measured as the standard deviation of monthly stock returns over the subsequent year.
} 


\section{Table VIII}

\section{New Issues Leverage and Equity Market Returns}

OLS regressions of annual real equity market returns on leverage and the equity share in new issues:

$$
R_{E t}=a+b_{1}(D / E)_{t-1}+b_{2} S_{t-1}+u_{t}
$$

where $R_{E}$ denotes real percentage returns on the CRSP value-weighted (VW) or equal-weighted (EW) portfolio, $D / E$ denotes the aggregate leverage ratio, and $S$ denotes the equity share in total new equity and debt issues. The sample includes returns from 1928 through 1996. Book leverage is from Statistics of Income: Corporation Income Tax Returns, Internal Revenue Service, and applies to the prior (fiscal) year. Market leverage is equal to book leverage capitalized at the prior-year book-to-market ratio of the Dow Jones Industrial Average. Both independent variables are standardized to have zero mean and unit variance. $t$-statistics are shown in brackets using heteroskedasticity robust standard errors.

\begin{tabular}{|c|c|c|c|c|c|c|}
\hline & \multicolumn{3}{|c|}{ VW CRSP } & \multicolumn{3}{|c|}{ EW CRSP } \\
\hline & (1) & (2) & (3) & (4) & (5) & (6) \\
\hline Intercept & $\begin{array}{c}8.56 \\
{[3.46]}\end{array}$ & $\begin{array}{c}8.56 \\
{[3.55]}\end{array}$ & $\begin{array}{c}8.63 \\
{[3.77]}\end{array}$ & $\begin{array}{l}13.98 \\
{[3.64]}\end{array}$ & $\begin{array}{l}13.98 \\
{[3.99]}\end{array}$ & $\begin{array}{l}14.08 \\
{[4.31]}\end{array}$ \\
\hline$D / E$ (book) & $\begin{array}{c}-0.66 \\
{[-0.27]}\end{array}$ & & & $\begin{array}{c}-1.28 \\
{[-0.36]}\end{array}$ & & \\
\hline$D / E$ (market) & & $\begin{array}{c}4.67 \\
{[1.81]}\end{array}$ & $\begin{array}{c}3.46 \\
{[1.71]}\end{array}$ & & $\begin{array}{l}13.06 \\
{[2.57]}\end{array}$ & $\begin{array}{l}11.07 \\
{[2.72]}\end{array}$ \\
\hline$S$ & & & $\begin{array}{c}-6.79 \\
{[-3.73]}\end{array}$ & & & $\begin{array}{l}-11.19 \\
{[-3.65]}\end{array}$ \\
\hline $\bar{R}^{2}$ & -0.01 & 0.04 & 0.14 & -0.01 & 0.16 & 0.27 \\
\hline$N$ & 69 & 69 & 69 & 69 & 69 & 69 \\
\hline
\end{tabular}

\section{Market Timing}

In this section we test market efficiency more generally by checking whether the equity share regression models forecast significantly negative returns. This approach avoids the joint hypothesis problem noted by Fama (1970), because the stock market must be a hedge against aggregate consumption for a rational model to predict negative returns. ${ }^{18}$

Several previous authors have performed this type of test, including Fama and Schwert (1977), Fama and French (1988a), and Kothari and Shanken (1997). Generally speaking, they do not find strong evidence against market efficiency. For example, Fama and French (1988a) look at whether the dividend yield predicts negative returns. Although sometimes negative, the forecast is never significantly negative. Kothari and Shanken (1997) find some negative return forecasts using the book-to-market ratio, and a large negative return forecast for the equal-weighted market portfolio in 1930. For this year, the hypothesis of a non-negative predicted return has a $p$-value of 0.02 .

\footnotetext{
${ }^{18}$ Merton $(1982,1990)$ lists conditions under which the theoretical risk premium is positive.
} 
However, that calculation assumes that conditional on the estimate of the slope, the intercept in the forecasting model is known, and thus the forecasting error comes from the slope alone. Kothari and Shanken report that without this assumption, the $p$-value rises to 0.10 even for 1930 . Finally, Campbell and Shiller (1998) note that the 1997 level of the dividend yield implies negative returns in the future, but they do not state their level of confidence. ${ }^{19}$

Our market return forecasts are presented in Table IX.$^{20}$ In a simple univariate model, the equity share predicts negative returns for six years: 1929, 1930, 1934, 1982, 1983, and 1984. (In three of these years, 1929, 1930, and 1984 , real returns actually were negative.) The first two columns show data on the equity share in those six years. Columns (3) and (4) show the forecast return and its standard error. Columns (5) and (6) test the hypothesis that predicted returns never fall below the sample average real government bond yield of 2.0 percent. This hypothesis is rejected at the five percent level for 1929, 1930, and 1984 equal-weighted and value-weighted returns and also for 1934 equal-weighted returns. Columns (7) and (8) test the hypothesis that predicted returns never fall below zero. This hypothesis is less theoretically motivated than the hypothesis of a non-negative risk premium, but it is also a lower hurdle for market efficiency to pass. Nevertheless, this hypothesis is still rejected at the five percent level for 1929 and 1930 valueweighted and equal-weighted returns and also for 1984 equal-weighted returns. These results can be compared to Kothari and Shanken's (1997) finding that $\mathrm{B} / \mathrm{M}$ forecasts significantly negative returns for only one year, 1930, and then at the 10 percent level.

The results are presented graphically in Figure 4. They apply to columns (7) and (8) of Table IX. The solid line shows predicted value-weighted returns in Figure 4A for the observed range of the prior-year equity share. Figure 4B shows predicted equal-weighted returns. The dashed lines contain a 90 percent confidence interval for the predicted return. In the region where the top dashed line falls below zero, we can reject non-negative returns at the five percent level. Figure 4A shows this for 1929 and 1930, and Figure $4 \mathrm{~B}$ shows this for 1929, 1930, and 1984. We also plot the actual returns. Many of the actual returns fall outside of the 90 percent confidence interval. Because the equity share explains only about 12 percent in the variation in value-weighted returns, the confidence interval for individual returns is considerably larger than the confidence interval for the mean return.

\footnotetext{
19 See Boudoukh, Richardson, and Smith (1993) for an alternative approach to testing the hypothesis of a nonnegative risk premium. They report evidence of a reliably negative risk premium during periods of high expected inflation and downward-sloping term structures.

${ }^{20}$ In the tests in Table IX, we assume that the predicted return is normally distributed. The predicted return will be asymptotically normal regardless of the distribution of returns, but it will only be normal in a small sample if the returns themselves are normally distributed. For value-weighted returns, we cannot reject the hypothesis of normality using a skewness-kurtosis test. The equal-weighted returns, by contrast, have skewness and excess kurtosis. For this reason, the equal-weighted results must be viewed as an approximation.
} 


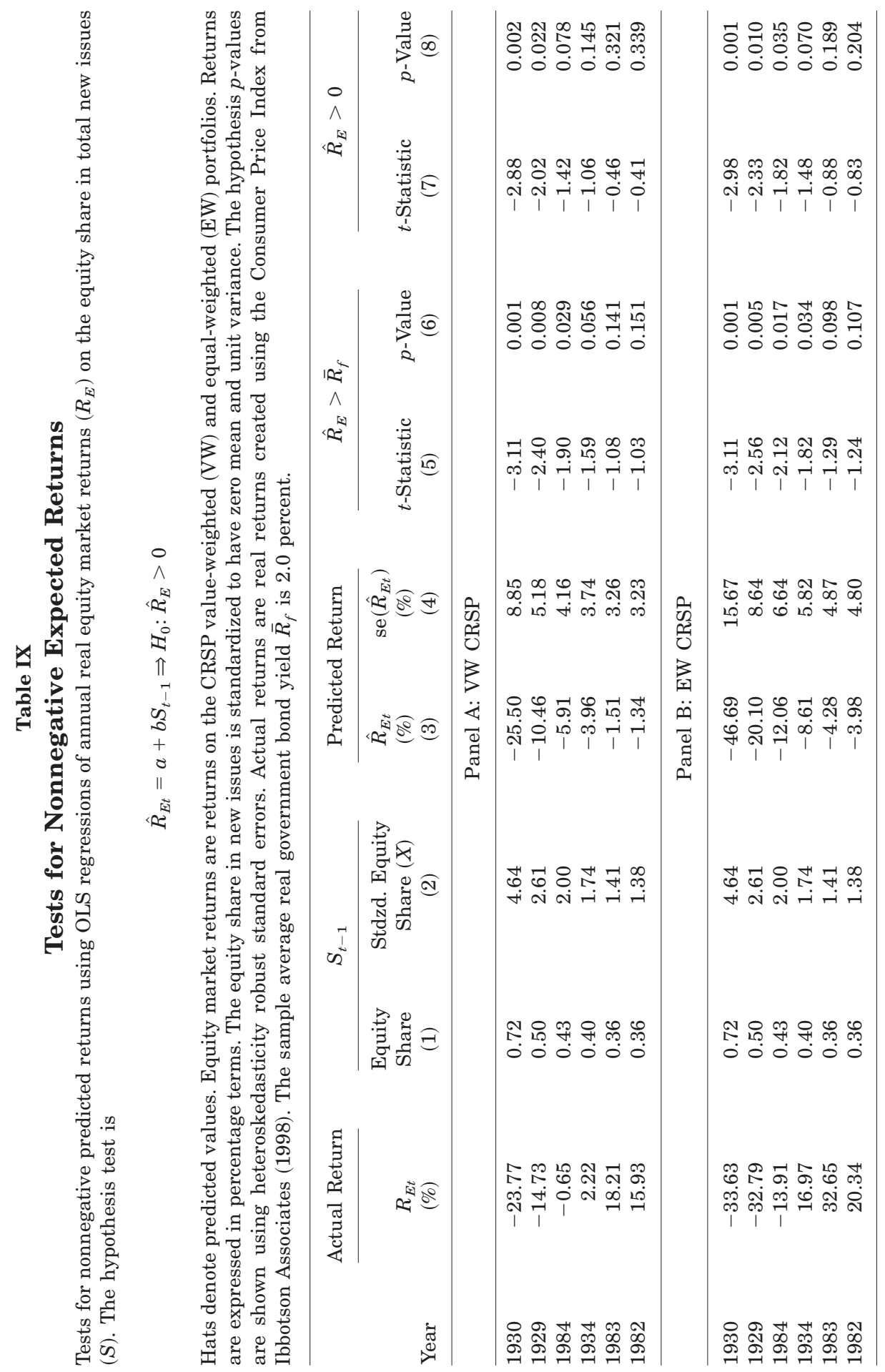


PANEL A. Predicted VW CRSP returns using the prior-year equity share.

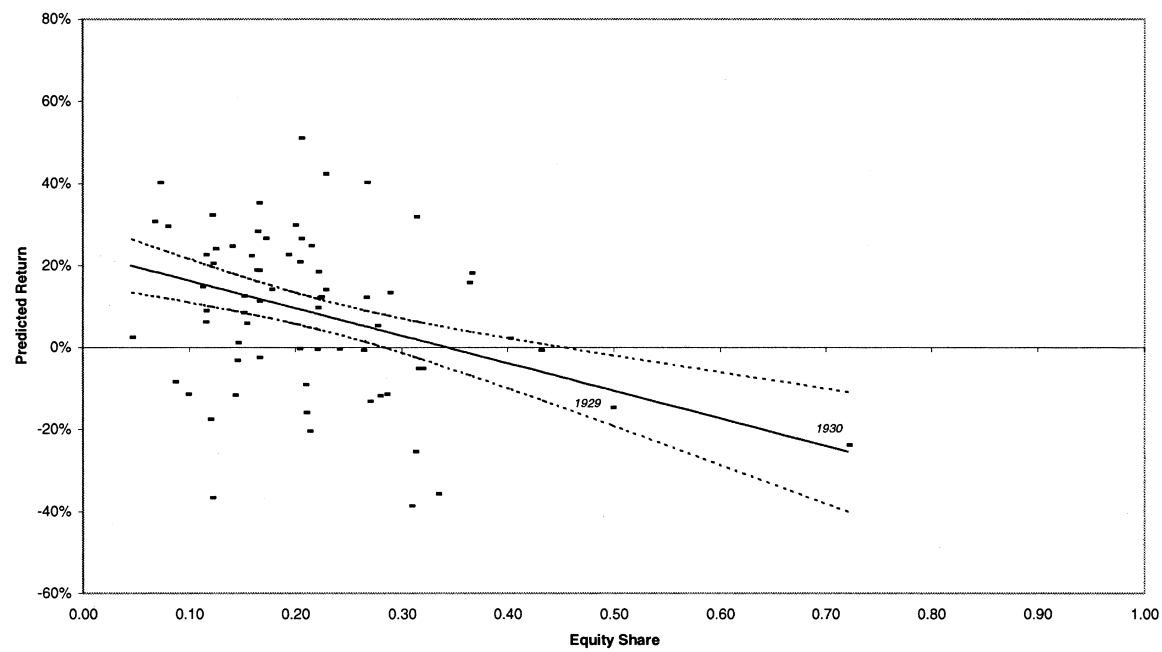

PANEL B. Predicted EW CRSP returns using the prior-year equity share.

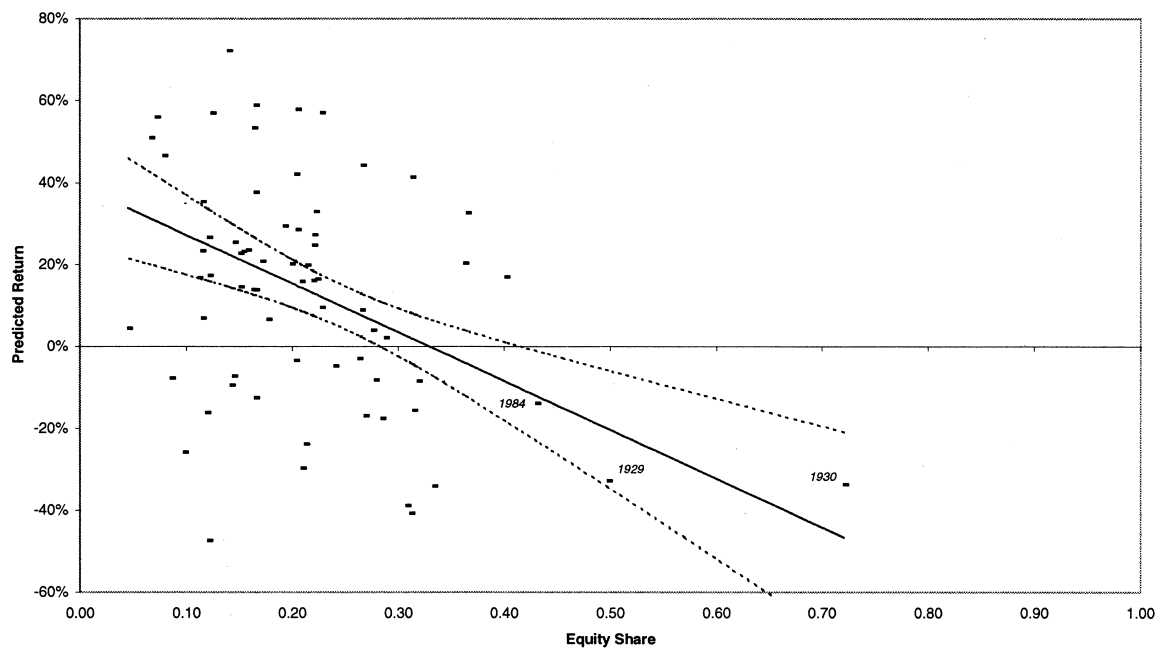

Figure 4. Predicted returns and the equity share. Figure 4A plots predicted one-yearahead real CRSP value-weighted returns using the prior-year equity share as a single predictor. Figure 4B plots predicted one-year real CRSP equal-weighted returns. (The year indicated is the return year; the equity share is measured in the prior year.) The dashed lines represent a 90 percent confidence interval for the predicted value. Dots represented realized returns.

To check for nonlinearity, we also estimate a predictive model that includes the equity share and its square. The squared term's coefficient is not significant, and including the squared term in the model does not change the set of years for which it predicts significantly negative returns. 
These negative return predictions cast a more general doubt on market efficiency and suggest that market timing drives our results. The story is intuitive. When investor sentiment causes, for example, overvalued equity prices, managers prefer to issue equity. Correlated investor sentiment implies that other firms will be overvalued at the same time and will therefore tend to make similar financing decisions. The final element is that arbitrage forces slowly-but eventually with some success-push the market back down to its efficient value. ${ }^{21}$ The upshot of these mechanics is that the equity share in new issues predicts aggregate returns, as we observe. As a corollary, to the extent that predictable variation in equity returns is driven mainly by mispricing and not rational time variation, the level of investment need not predict returns.

Consistent with managers timing a market periodically driven by irrational sentiment, the equity share in new issues is related to various measures of investor optimism. Changes in the equity share are strongly positively correlated with changes in aggregate insider sales of stock, negatively (though insignificantly) correlated with changes in the value-weighted closed-end fund discount, and positively correlated with changes in consumers' expectations of business conditions. ${ }^{22}$ These correlations are consistent with previous findings that insider trading profits reflect timing ability and that closed-end fund discounts and consumer sentiment capture investor sentiment. ${ }^{23}$

On the basis of this collection of evidence, we conclude that market timing drives our results. Managers appear to time their issues to exploit not only the idiosyncratic component of their firm's returns but also the market component.

Two final notes are worth making about this timing explanation. First, if there is a distinction between new equity for investment and new equity for pure speculation, it is not apparent in our aggregate data. We interact investment with the equity share to test the hypothesis that the predictability of the equity share is primarily in periods of low investment. The coefficient on this interaction term has the predicted positive sign but is not significantly different from zero. Second, if firms' issuance decisions reflect their views about equity valuations, they seem to be ignoring the dividend yield and the book-to-market ratio. As mentioned previously, the correlation be-

\footnotetext{
${ }^{21}$ Shleifer (2000) reviews models of investor sentiment and limited arbitrage.

${ }^{22}$ All correlations are measured using quarterly data. Using data on insider trading from Jeng, Metrick, and Zeckhauser (1999) over the period from 1976 through 1996, we find that the correlation of changes in the equity share with changes in insider net sales is $0.36(p<0.01)$. Using closed-end fund data provided by Charles Lee and CDA Weisenberger over the period from 1965 through 1996, we find that the correlation of changes in the equity share with changes in the value-weighted closed-end fund discount calculated is $-0.08(p=0.39)$. Finally, changes in expectations of business conditions from 1978 through 1996, from the Index of Consumer Sentiment, have a $0.19(p=0.10)$ correlation with changes in the equity share.

${ }^{23}$ Seyhun (1992), Lee (1997), and Jeng et al. (1999) find that insiders earn abnormal profits. Lee, Shleifer, and Thaler (1991) find that the number of IPOs increases when closed-end fund discounts are low. Durell (1999) finds that consumer sentiment is strongly correlated with closed-end fund discounts.
} 
tween the equity share and the scaled-price variables is insignificant. This suggests that even though the equity share does not appear to be linked to rational variation in the discount rate, the dividend yield and book-tomarket ratio may be.

\section{Summary and Implications}

The main result of this paper is that issuing firms tend to prefer equity finance before periods of low returns and tend to shun equity, in favor of debt, before periods of high returns. From a narrow statistical perspective, one can make a good case that the equity share in new issues is stronger and more robust than other known predictors of one-year-ahead market returns.

We do not find empirical support for any specific mechanism that could link the equity share to subsequent returns even in an efficient market. Instead, we believe this study offers some suggestive evidence that the stock market as a whole may be inefficient and that managers exploit this inefficiency with their financing decisions. In particular, the equity share sometimes predicts significantly negative returns on the market.

If this view is correct, and managerial timing of the market component of returns is possible, then our results raise questions about how one should view long-run event studies of managerial actions. As an example, Brav and Gompers (1997), Brav et al. (2000), and Mitchell and Stafford (2000) find that some of the "new issues puzzle" results depend on the benchmark used. They show that equity issuers do not perform worse than certain sets of nonissuers in the first term of the decomposition $R_{i}=\left(R_{i}-R_{b}\right)+R_{b}$. Mitchell and Stafford and particularly Fama (1998) point to this as evidence that issuers' low returns reflect their risk characteristics.

Although one wonders how IPOs could ever plausibly be considered low risk investments (and therefore deserving low returns), our results also raise a methodological issue. Looking only at the excess return hides the fact that both issuers and benchmark firms often simultaneously experience unusually low subsequent returns, as Brav and Gompers show in IPO data. If the ability to time the market component of returns is a significant determinant of managerial actions, as suggested by our results, long-run event studies that ignore this consideration may be ignoring a big part of the story.

We suspect this benchmarking problem is relevant to other events where a market timing motive is suspected, such as insider trading, repurchases, and stock acquisitions, in addition to the new issues puzzle and financing decisions. Researchers should be wary of this issue when interpreting longrun event studies of managerial actions.

\section{Appendix A. Alternative Definitions of the Equity Share}

In the body of the paper we use the gross new equity and debt issues data reported by the Federal Reserve Bulletin to compute the equity share. Here we consider the impact of using other measures of equity and debt issuance. 
Table AI summarizes the results. In the first row we repeat, for reference, the basic predictive ability of the unadjusted equity share for valueweighted and equal-weighted market returns as in Table III.

In the first adjustment we consider, we subtract repurchases from the gross new equity issues series. The repurchase data, from 1977 through 1996, combine annual observations from Bagwell and Shoven (1989) with more recent data from the Securities Data Company. Prior to 1977, we make no adjustment. The resulting series has a correlation of 0.90 with the unadjusted series (a correlation of 1.00 before 1977 and 0.86 after) and has similar predictive power. ${ }^{24}$ The second adjustment subtracts convertibles and junk debt from the gross debt issues series. These issues may bear more resemblance to equity than straight debt. We gather convertible debt and junk debt back to 1978 from the Securities Data Company. Prior to 1978, we make no adjustment. The results are unaffected. The third adjustment subtracts issues by utilities from both the equity and debt series. Issuance by utilities may result from regulatory changes rather than market timing motives. We gather utilities issue data from the Federal Reserve Bulletin back to 1961 . Prior to 1961, we make no adjustment. This does not change the basic results. The fourth adjustment combines the first three, again with little change to the basic results.

We also consider the Federal Reserve Board's flow of funds data. These series measure net equity and net debt issues. One significant advantage, relative to the unadjusted series, is that the flow of funds series net out equity repurchases and debt retirements. Unfortunately, there are offsetting disadvantages. The most severe is that variation in the series often comes from the retirement of equity in mergers and acquisitions. The gross equity issues series, by contrast, counts only equity issues for cash. As a result, the gross series may better reflect operations financing patterns. A second unfortunate limitation is that the flow of funds series begins in 1946 .

Net equity issues are negative in 14 of the 51 years for which flow of funds data are available. This can cause a practical problem. When the $e$ in $S=$ $e /(e+d)$ is negative and large, it can yield an absurd value for the equity share. For example, in 1989 , net equity issues were $-\$ 115.2$ billion, and net debt issues were $\$ 114.6$ billion. Plugging these figures into the equity share formula gives a value of 192 ! In an attempt to forge a meaningful equity share series from the flow of funds data, we simply set the equity share to zero in years where net equity issues are negative. This convention assumes that years in which net equity issues are negative are likely to be years in which equity was not the preferred vehicle for new finance. This truncation also mitigates the effect of merger activity.

\footnotetext{
${ }^{24}$ The Bagwell and Shoven series may suffer from some survivorship bias, as it does not use the Compustat research files. We obtained similar results using the repurchase series reported in Table II of Allen and Michaely (1995), which employs both the industrial and research files to compute repurchases by the 1,000 largest firms in COMPUSTAT for each year between 1973 and 1991.
} 


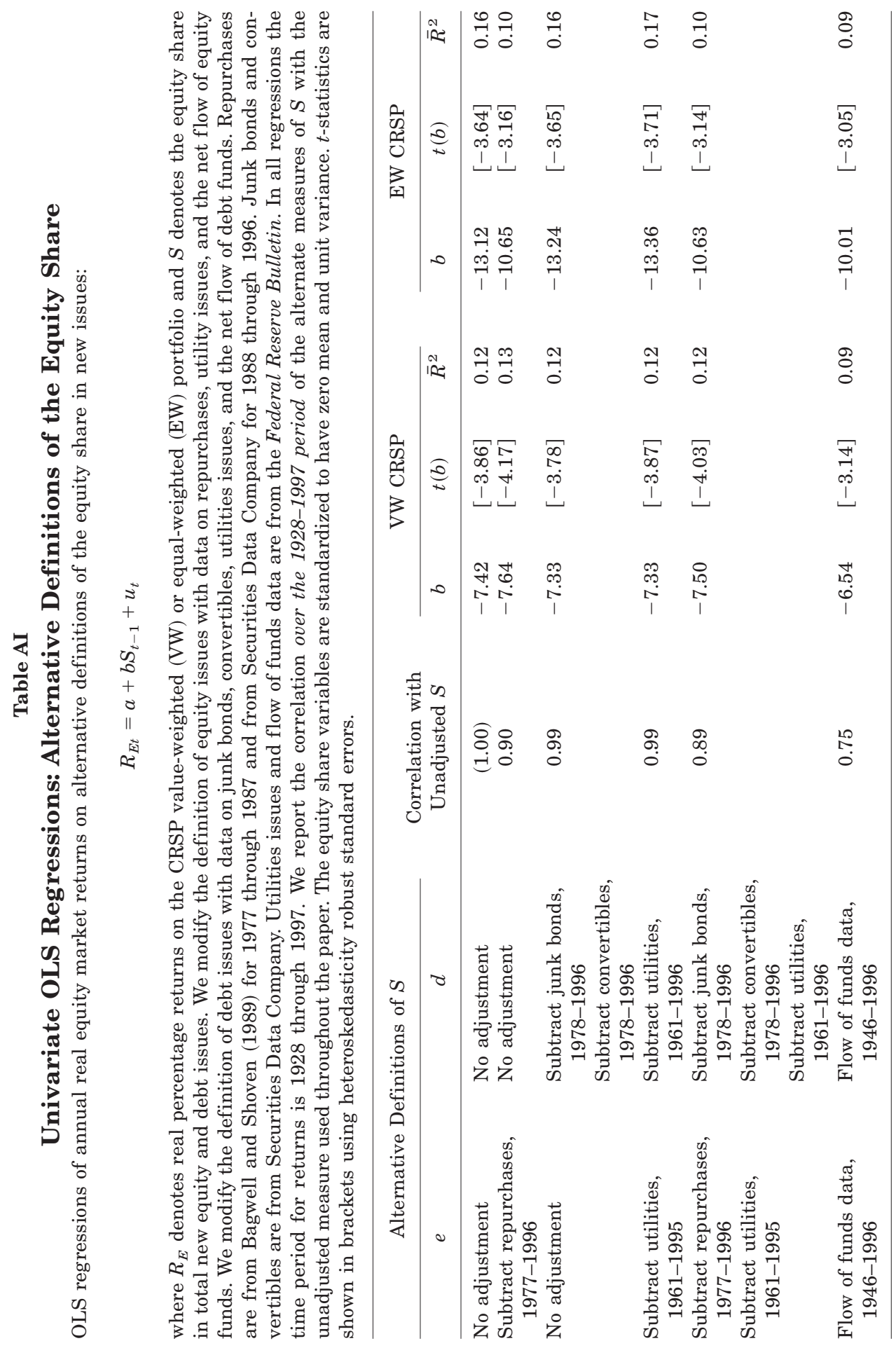


The resulting 1946 to 1996 flow of funds equity share series has a correlation of 0.65 with the unadjusted series. That is, net equity issues relative to total net issues is highly correlated with gross issues relative to net gross issues, our unadjusted equity share. Splicing the 1927 to 1945 unadjusted equity share series to the 1946 to 1996 flow of funds net series naturally results in a longer series with a slightly higher correlation with the full unadjusted series, 0.75 . And again, this series retains strong predictive power for both EW and VW market returns.

Taken together, these exercises suggest that little predictive power is lost by using the unadjusted measure of the equity share. Adjustments for convertible debt, junk debt, repurchases, or issuance by utilities do not make much practical difference, for better or worse. Similarly, the equity share series constructed using flow of funds data yields a similar coefficient and similar predictive power. Given these results, we prefer the unadjusted equity share series because of its transparency and historical consistency.

\section{Appendix B. Mathematical Appendix}

This appendix derives the empirical predictions presented in Table VI. The manager's objective function is

$$
\max _{S, I} f(I)-\left(1+E\left[R_{A}\right]\right) I-\delta S I-i(S I)-z((S-\bar{S}) I)
$$

where

$$
\begin{gathered}
f^{\prime}>0, f^{\prime \prime}<0, \\
i^{\prime}<0, i^{\prime \prime}>0 \text { when } S<0 \text { and } i^{\prime}>0, i^{\prime \prime}>0 \text { when } S>0, \\
z^{\prime}<0, z^{\prime \prime}>0 \text { when } S<\bar{S} \text { and } z^{\prime}>0, z^{\prime \prime}>0 \text { when } S>\bar{S}
\end{gathered}
$$

The manager chooses the equity share $S$ (the share of equity issues in total equity and debt issues) and the level of total equity and debt issues $I$. The setup is discussed in more detail in Section III.B and in Stein (1996).

The optimal equity share $S$ and investment $I$ satisfies the first order conditions

$$
\begin{aligned}
f^{\prime}(I)+z^{\prime}((S-\bar{S}) I) \bar{S} & =\left(1+E\left[R_{A}\right]\right) \\
\delta+i^{\prime}(S I)+z^{\prime}((S-\bar{S}) I) & =0 .
\end{aligned}
$$

These two equations allow us to calculate comparative statics: how the equity share $S$ and the level of investment $I$ respond to changes in the determinants of equity returns, $E\left[R_{A}\right]$ and $\delta$. 


\section{A. Investment and Financing Policy in an Efficient Market}

In this case, rational expected returns $E\left[R_{A}\right]$ may vary over time, but $\delta$ is always zero. To see what this implies for the relationship between the equity share, investment, and future returns, we differentiate equations (B2) and (B3) with respect to $E\left[R_{A}\right]$. This gives

$$
f^{\prime \prime}(I) \frac{d I}{d E\left[R_{A}\right]}+z^{\prime \prime}((S-\bar{S}) I) \bar{S}\left(I \frac{d S}{d E\left[R_{A}\right]}+(S-\bar{S}) \frac{d I}{d E\left[R_{A}\right]}\right)=1
$$

and

$$
i^{\prime \prime}(S I)\left(I \frac{d S}{d E\left[R_{A}\right]}+S \frac{d I}{d E\left[R_{A}\right]}\right)+z^{\prime \prime}((S-\bar{S}) I)\left(I \frac{d S}{d E\left[R_{A}\right]}+(S-\bar{S}) \frac{d I}{d E\left[R_{A}\right]}\right)=0
$$

From the two equations, there are two comparative statics:

$$
\left[\begin{array}{c}
\frac{d I}{d E\left[R_{A}\right]} \\
\frac{d S}{d E\left[R_{A}\right]}
\end{array}\right]=\frac{1}{|\mathbf{A}|}\left[\begin{array}{c}
i^{\prime \prime} I+z^{\prime \prime} I \\
-i^{\prime \prime} S-z^{\prime \prime}(S-\bar{S})
\end{array}\right]
$$

where

$$
\mathbf{A}=\left[\begin{array}{cc}
f^{\prime \prime}+z^{\prime \prime} \bar{S}(S-\bar{S}) & z^{\prime \prime} \bar{S} I \\
i^{\prime \prime} S+z^{\prime \prime}(S-\bar{S}) & i^{\prime \prime} I+z^{\prime \prime} I
\end{array}\right]
$$

Although these equations appear complicated, they are not difficult to evaluate. First, because the determinant of $\mathbf{A}$ is negative and the second derivatives of $i$ and $z$ are positive, investment is always negatively related to future returns. Second, when there is no mispricing, it is straightforward to show that the equity share falls between zero and $\bar{S}$ by equation (B3). As a consequence, the relationship between the equity share and future returns depends on whether the information costs $i$ or the costs of deviating from optimal capital structure $z$ are more important. When $i$ dominates, the equity share is positively related to future returns. When $z$ dominates, the equity share is negatively related to future returns. 


\section{B. Investment and Financing Policy in an Inefficient Market}

In this case, rational returns $E\left[R_{A}\right]$ are constant and $\delta$ varies. To determine the empirical predictions of this setup, we differentiate equations (B2) and (B3) with respect to $\delta$. This gives

$$
\begin{gathered}
f^{\prime \prime}(I) \frac{d I}{d \delta}+z^{\prime \prime}((S-\bar{S}) I) \bar{S}\left(I \frac{d S}{d \delta}+(S-\bar{S}) \frac{d I}{d \delta}\right)=0 \\
i^{\prime \prime}(S I)\left(I \frac{d S}{d \delta}+S \frac{d I}{d \delta}\right)+z^{\prime \prime}((S-\bar{S}) I)\left(I \frac{d S}{d \delta}+(S-\bar{S}) \frac{d I}{d \delta}\right)=-1 .
\end{gathered}
$$

From the two equations, there are two comparative statics:

$$
\left[\begin{array}{c}
\frac{d I}{d \delta} \\
\frac{d S}{d \delta}
\end{array}\right]=\frac{1}{|\mathbf{A}|}\left[\begin{array}{c}
z^{\prime \prime} \bar{S} I \\
-\left(f^{\prime \prime}+z^{\prime \prime} \bar{S}(S-\bar{S})\right)
\end{array}\right]
$$

where the matrix $\mathbf{A}$ is the same as in equation (B7).

Again, we evaluate the expressions. First, the relationship between investment and mispricing is negative. The determinant of $\mathbf{A}$ is negative, and the second derivative of $z$ is positive. However, the magnitude of this relationship is proportional to the costs of deviating from optimal leverage $z$. At the limit when information costs $i$ dominate, investment is unrelated to mispricing. Second, the relationship between equity issues and mispricing depends on the parameters. When $i$ dominates, the equity share is negatively related to mispricing, because the second derivative of $f$ is negative. When $z$ dominates, the relationship depends on the level of mispricing. If $\delta$ is sufficiently low, the level of equity issues will exceed the optimal capital structure $\bar{S}$. In this case, it is possible (although perhaps unlikely) for the level of equity issues to move positively with mispricing. When $\delta$ is higher, equity issues are negatively related to future returns.

\section{REFERENCES}

Allen, Franklin, and Roni Michaely, 1995, Dividend policy; in Robert A. Jarrow, Vojislav Maksimovic, and William T. Ziemba, eds.: Finance (Elsevier, Amsterdam).

Ahn, Dong-Hyun, and Anil Shivdasani, 1999, Long-term returns following seasoned equity issues: Bad performance or bad model? Working paper, University of North Carolina.

Bagwell, Laurie Simon, and John B. Shoven, 1989, Cash distributions to shareholders, Journal of Economic Perspectives 3, 129-140.

Boudoukh, Jacob, Matthew Richardson, and Tom Smith, 1993, Is the ex ante risk premium always positive? Journal of Financial Economics 34, 387-408.

Brav, Alon, Christopher Geczy, and Paul A. Gompers, 2000, Is the abnormal return following equity issuances anomalous? Journal of Financial Economics, forthcoming. 
Brav, Alon, and Paul A. Gompers, 1997, Myth or reality? The long-run underperformance of initial public offerings: Evidence from venture capital and nonventure capital-backed companies, Journal of Finance 52, 1791-1822.

Campbell, John Y., and Robert Shiller, 1988, The dividend price ratio and expectations of future dividends and discount factors, Review of Financial Studies 1, 195-228.

Campbell, John Y., and Robert Shiller, 1998, Valuation ratios and the long-run stock market outlook, Journal of Portfolio Management 24, 11-26.

Choe, Hyuk, Ronald W. Masulis, and Vikram Nanda, 1993, Common stock offerings across the business cycle: Theory and evidence, Journal of Empirical Finance 1, 3-31.

Cornett, Marcia M., Hamid Mehran, and Hassan Tehranian, 1998, Are financial markets overly optimistic about the prospects of firms that issue equity? Evidence from voluntary versus involuntary equity issuances by banks, Journal of Finance 53, 2139-2159.

De Long, J. Bradford, and Andrei Shleifer, 1991, The stock market bubble of 1929: Evidence from closed-end mutual funds, Journal of Economic History 51, 675-700.

Durell, Alan, 1999, Consumer confidence and stock market returns, Working paper, Harvard University.

Eckbo, B. Espen, Ronald A. Masulis, and Oyvind Norli, 2000, Seasoned public offerings: Resolution of the "new issues puzzle," Journal of Financial Economics 56, 251-292.

Fama, Eugene F., 1970, Efficient capital markets: A review of theory and empirical work, Journal of Finance 25, 383-417.

Fama, Eugene F., 1998, Market efficiency, long-term returns, and behavioral finance, Journal of Financial Economics 49, 283-306.

Fama, Eugene F., and Kenneth R. French, 1988a, Dividend yields and expected stock returns, Journal of Financial Economics 22, 3-25.

Fama, Eugene F., and Kenneth R. French, 1988b, Permanent and temporary components of stock prices, Journal of Political Economy 96, 246-273.

Fama, Eugene F., and G. William Schwert, 1977, Asset returns and inflation, Journal of Financial Economics 5, 115-146.

Friend, Irwin, and Edward S. Herman, 1964, The S.E.C. through a glass darkly, Journal of Business 37, 382-405.

Friend, Irwin, and James R. Longstreet, 1967, Price experience and return on new stock issues; in Irwin Friend, James R. Longstreet, Morris Mendelson, Ervin Miller, and Arleigh P. Hess, Jr., eds.: Investment Banking and the New Issues Market (World Publishing Co., Cleveland).

Hickman, W. Braddock, 1953, The Volume of Corporate Bond Financing (National Bureau of Economic Research, New York).

Ibbotson Associates, 1998, Stocks, Bonds, Bills, and Inflation (Ibbotson Associates, Chicago).

Ibbotson, Roger G., and Jeffrey F. Jaffe, 1975, "Hot issue" markets, Journal of Finance 30, 1027-1042.

Ikenberry, David, Josef Lakonishok, and Theo Vermaelen, 1995, Market underreaction to open market share repurchases, Journal of Financial Economics 39, 181-208.

Jain, Bharat A., and Omesh Kini, 1994, The post-issue operating performance of IPO firms, Journal of Finance 49, 1699-1726.

Jeng, Leslie A., Andrew Metrick, and Richard J. Zeckhauser, 1999, Estimating the returns to insider trading: A performance-evaluation perspective, Working paper, Harvard University.

Keim, Donald B., and Robert F. Stambaugh, 1986, Predicting returns in bond and stock markets, Journal of Financial Economics 12, 357-390.

Kendall, M. G., 1954, Note on bias in estimation of auto-correlation, Biometrika 41, 403-404.

Kothari, S. P., and Jay Shanken, 1997, Book-to-market, dividend yield, and expected market returns: A time-series analysis, Journal of Financial Economics 44, 169-203.

Lamont, Owen, 1998, Earnings and expected returns, Journal of Finance 53, 1563-1587.

Lee, Charles M. C., Andrei Shleifer, and Richard H. Thaler, 1991, Investor sentiment and the closed-end fund puzzle, Journal of Finance 46, 75-109.

Lee, Inmoo, 1997, Do firms knowingly sell overvalued equity? Journal of Finance 52, 1439-1466. 
Lerner, Joshua, 1994, Venture capitalists and the decision to go public, Journal of Financial Economics 35, 293-316.

Loughran, Tim, and Jay Ritter, 1995, The new issues puzzle, Journal of Finance 50, $23-51$.

Loughran, Tim, and Jay Ritter, 1997, The operating performance of firms conducting seasoned equity offerings, Journal of Finance 52, 1823-1850.

Loughran, Tim, Jay Ritter, and Kristian Rydqvist, 1994, Initial public offerings: International insights, Pacific-Basin Finance Journal 2, 165-199.

Loughran, Tim, and Anand M. Vijh, 1997, Do long-term shareholders benefit from corporate acquisitions? Journal of Finance 52, 1765-1790.

Marsh, Paul, 1982, The choice between equity and debt: An empirical study, Journal of Finance 37, 121-144.

Merton, Robert C., 1982, On the microeconomic theory of investment under uncertainty; in Kenneth J. Arrow and Michael D. Intriligator, eds.: Handbook of Mathematical Economics, Vol. II (North-Holland, Amsterdam).

Merton, Robert C., 1990, Capital market theory and the pricing of financial securities; in Benjamin Friedman and Frank Hahn, eds.: Handbook of Monetary Economics (North-Holland, Amsterdam).

Mikkelson, Wayne H., Megan Partch, and Ken Shah, 1997, Ownership and operating performance of companies that go public, Journal of Financial Economics 44, 281-307.

Mitchell, Mark L., and Erik Stafford, 2000, Managerial decisions and long-term stock price performance, Journal of Business, forthcoming.

Modigliani, Franco, and Merton H. Miller, 1958, The cost of capital, corporation finance, and the theory of investment, American Economic Review 48, 655-669.

Moore, Geoffrey H., 1983, Business Cycles, Inflation and Forecasting, National Bureau of Economic Research Studies in Business Cycles, no. 24 (Ballinger Publishing Company, Cambridge).

Myers, Stewart C., and Nicholas S. Majluf, 1984, Corporate financing and investment decisions when firms have information that investors do not have, Journal of Financial Economics 13, 187-221.

Nelson, Charles R., and Myung Kim, 1993, Predictable stock returns: The role of small sample bias, Journal of Finance 48, 641-661.

Nelson, William R., 1999, The aggregate change in shares and the level of stock prices, Working paper, Federal Reserve Board.

Pagano, Marco, Fabio Panetta, and Luigi Zingales, 1998, Why do companies go public? An empirical analysis, Journal of Finance 53, 27-64.

Peavy, John W., 1990, Returns on initial public offerings of closed-end funds, Review of Financial Studies 3, 695-708.

Pontiff, Jeffrey, and Lawrence D. Schall, 1998, Book-to-market ratios as predictors of market returns, Journal of Financial Economics 49, 141-160.

Poterba, Jim, and Lawrence H. Summers, 1988, Mean reversion in stock returns: Evidence and implications, Journal of Financial Economics 22, 27-60.

Rajan, Raghuram, and Henri Servaes, 1997, Analyst following of initial public offerings, Journal of Finance 52, 507-529.

Ritter, Jay, 1991, The long-run performance of initial public offerings, Journal of Finance 42, $365-394$.

Seyhun, H. Nejat, 1992, Why does aggregate insider trading predict future stock returns? Quarterly Journal of Economics 107, 1303-1331.

Shleifer, Andrei, 2000, Inefficient Markets: An Introduction to Behavioral Finance (Oxford University Press, Oxford).

Speiss, D. Katherine, and John Affleck-Graves, 1995, Underperformance in long-run stock returns following seasoned equity offerings, Journal of Financial Economics 38, 243-267.

Stambaugh, Robert F., 2000, Predictive regressions, Journal of Financial Economics 54, 375421.

Stein, Jeremy C., 1996, Rational capital budgeting in an irrational world, Journal of Business $69,429-455$. 
Stigler, George J., 1964, Public regulation of the securities markets, Journal of Business 37, $117-142$.

Teoh, Siew Hong, Ivo Welch, and T. J. Wong, 1998a, Earnings management and the long-run market performance of initial public offerings, Journal of Finance 53, 1935-1974.

Teoh, Siew Hong, Ivo Welch, and T. J. Wong, 1998b, Earnings management and the underperformance of seasoned equity offerings, Journal of Financial Economics 50, 63-99.

Weiss, Kathleen, 1989, The post-offering price performance of closed-end funds, Financial Management 18, 57-67. 
2258 